\title{
Language in Congress: Domestic Constituent Influence in Foreign Aid Decisions
}

\author{
Esol Cho*
}

September 16, 2021

\begin{abstract}
There is an extensive literature on the effect of donor ideology on foreign aid allocations. However, the process through which donor ideology influences aid decisions is understudied. In my framework, legislators' application of domestic political ideology is expanded to foreign aid agendas through interactions with domestic constituencies: development Non-Governmental Organizations (NGOs) and private enterprises. Legislators adopt the constituencies' ideological rationale for aid and reflect the groups' aid preferences by taking on the language of those constituents. To test this theoretical expectation, I applied the Structural Topic Model (STM) and Wordfish to my self-collected text data on testimonial statements given by representatives of NGOs and of firms at U.S. Congressional Hearings for foreign aid and floor speeches of left- and right-leaning legislators from the Congressional Record relating to foreign aid. My results suggest that constituent groups have an influence on the ideological aid positions of individual legislators, which, in turn, may translate into the aid decisions of the donor country, in this case the US.
\end{abstract}

Word Count: 9,934

*PhD Candidate, Binghamton University, echo33@binghamton.edu 


\section{Introduction}

Permit me to begin by challenging the widely held belief that there is no American constituency for foreign assistance. While there has been little vociferous support for foreign aid such as you receive on various other issues of no greater and no less importance, I can assure you that from the PVO (Private Voluntary Organization) point of view, we see and hear from American constituents for foreign assistance every day. They call us, they write us and they send us their donations. These constituents created and govern and sustain the international private development effort. In the larger sense, these people are America's private voluntary organizations and it is they whom I am representing here today.

—Kenneth H. Phillips, President, Interaction, 28 February $1989^{1}$

The idea that there is no domestic constituency for foreign aid has been more or less considered a given as most beneficiaries of aid are foreigners who neither pay for it nor vote in the donor country. However, according to the quote from the president of InterAction-the U.S. network body for Non-Governmental Organizations (NGOs)_public preferences for aid are mobilized, organized, and represented by development NGOs. These organizations engage in aid and relief work as a way of serving their own constituents who are well-informed about foreign aid issues and are interested in supporting the socioeconomic well-being of people in myriad ways and contexts including in other countries. Individual politicians thus likely consider the NGOs and the people who volunteer for and provide private donations to them to be important not only as potential voters but also as political donors who could help raise donations to support the politicians' own careers.

Focusing on domestic interest groups' engagement including the NGOs in participating in the legislative process and legislators' political interest in building a relationship with these groups, I explore how constituent interests shape donors' aid decision-making process. By differentiating between the kinds of constituent groups and exploring the respective roles of development NGOs and private enterprises, my research suggests that donors' ideological preferences in relation to aid are grounded in their interactions with constituencies that developed to reflect those aid demands. The relationship between partisan ideology and foreign aid allocations has been studied extensively. In contrast, the process through which donor ideology influences aid decisions is understudied. Few

\footnotetext{
1 The quote is from the U.S. Congressional Hearing titled "Review of the Task Force on Foreign Assistance" held by the House Foreign Affairs Committee (citation number HRG-1989-FOA-0100).
} 
studies investigate either the origins of donors' ideological preferences or the ways in which donor ideology shapes governments' aid policy choices.

In the standard account, the role of ideology in donors' aid decisions has been described as arising from a set of either left-leaning or right-leaning beliefs held by policymakers as determined by their respective partisan orientations. Accordingly, the policy preferences of leftist and rightist governments in relation to aid have been illustrated as pro- and anti-aid positions or as aid proceeding from selfless or selfish motives. For example, leftist governments support development assistance and use it to alleviate poverty and inequality on a global basis (Thérien and Noel 2000; Brech and Potrafke 2014). On the other hand, either rightist governments do not provide foreign aid on the basis that it can harm the market efficiency of recipient countries (Thérien 2002, 460) or they do provide aid but only as a tool to promote export and investment (Fleck and Kilby 2006). Focusing on policy preferences of individual legislators as opposed to donor governments as a whole, my study explores variations in the left-right ideological stance, suggesting that policy actions in relation to aid taken by parties and politicians may shift depending on how they interact with domestic constituencies. I argue that the focus of donors' aid allocations is determined by a social rather than an ideational process in which the political actors' ideological preferences are translated into aid policy outcomes in the domestic politics of donor states.

In my framework, domestic constituent groups connect with legislators with the goal of persuading them to advance a given aid policy agenda and use the legislative process as a forum for expressing their aid preferences. To bring political pressure to bear on the legislators, the groups emphasize the broader community they represent and provide a rationale for foreign aid choices coupled with a set of specific policy options. In response, legislators strategically support the rationale offered, adopt the group's argument and language as their own, depending on the political utility they expect to gain by working with the group, and thereby demonstrate their loyalty to the constituencies. Through the interaction with any given constituent group, legislators extend the application of their ideology from a principal focus on domestic issues to the context of foreign aid 
issues. As a result, we can observe a correspondence between the language used by the constituent group and the language used by legislators who are sympathetic to its position.

To test the correspondence in terms of aid policy agenda between legislators and constituencies, I employed quantitative text analysis methods. I created my original corpus by collecting testimonial statements made by non-departmental witnesses during the U.S. Congressional hearings for foreign aid and floor speeches made by legislators relating to foreign aid. Using text-as-data methods, I estimated the clusters of words that the interest groups and politicians would have in common in accordance with their ideological linkage.

In terms of testing my argument relating to the influence of domestic constituent groups on donors' aid decisions, text analysis techniques are critical in three ways. First, testimonies given during legislative hearings are a good source of data given that individual witnesses directly state their policy preferences. The primary reason for the presence of witnesses at these hearings is their desire to express their issue positions on a given agenda with the express purpose of getting the needs of their group met in the decision-making process. Furthermore, testimonial documents are useful because they are highly comparable in both syntax and semantics. Many speakers put their remarks in the same way more or less as a habitual practice, thereby delivering their speeches effectively within the short timeframe (3-5 minutes) allocated and showing courtesy to the legislators and policymakers on the given committee. ${ }^{2}$ Technically, the automated procedure of computational text analysis ensures a precise and reliable result, making it possible to systematically process a large volume of texts from many witnesses across multiple years. Second, the unsupervised learning algorithm trained for my research identifies aid issue dimensions salient to two main domestic constituencies, i.e., development NGOs and private enterprises. Measuring the aid policy preferences of both kinds of groups demonstrates the impact of constituencies working in the legislative process, instead of making possibly unwarranted assumptions about their influence in

\footnotetext{
2 For example, an oral testimony given at the U.S. Congressional hearings can be outlined as follows: the witnesses (1) identify themselves and the organization they represent; (2) offer greetings and/or gratitude to the committee chair and the committee members for the invitation to speak; (3) state their position on the proposed bill or policy agenda; (4) offer concluding remarks restating or reviewing their position at the end of the testimony; and (5) thank the chair for the opportunity to speak.
} 
this sphere. Third, by analyzing the language that legislators and domestic constituencies use in Congress, I demonstrate whether and the extent to which the words of these two kinds of actors correspond to one another, which provides a sound foundation for determining how the legislators develop their ideological preferences for aid in a process of broadening their application of ideology through interacting with the constituent groups.

\section{Donor Ideology, Constituent Aid Interests, and Aid Testimonies}

\section{Constituent Interests}

In my account of donor aid decisions, development NGOs and private enterprises are considered to be the main constituent groups in donor states. Aid constituencies are domestic interest groups that lobby the legislative and executive branches of government on foreign aid issues (Lancaster 2008). Development NGOs are organizations that specialize in providing goods and services for development and humanitarian relief in an effort to alleviate poverty. Examples are Oxfam, Save the Children, and InterAction, and more broadly think-tanks, universities, and churches can also be included in this category. For private enterprises, examples are business groups particularly in the production, construction, and infrastructure sectors. Associations such as trade unions and agricultural producer groups can also be included in the private enterprise category.

The constituent power of both the NGOs and the firms originates from their roles representing different segments of civil society based on their relationships with a wide range of individuals and groups at the local and regional levels. Development NGOs incorporate not only group leaders and staff members but also activists, volunteers, private donors and interested members of the general public. Foreign aid programs put in place to promote business opportunities for domestic companies in the international market are supported by a majority of society, catalyzing export growth and thus benefiting domestic taxpayers. Further, both the NGOs and the business enterprises organize network associations to collectively express their demands, which means they can bring stronger constituent pressure to bear on government policymaking. Examples of network bodies engaged in U.S. aid work are InterAction and the Interreligious Task Force on U.S. Food Policy for NGOs and 
the Coalition for Employment through Exports, the American Wind Energy Association, and the Micro-Enterprise Coalition for firms. As of May 2021, InterAction had 178 member organizations and raised $\$ 15$ billion in private funding. The Coalition for Employment through Exports focuses on bringing policy and education efforts together to promote the competitiveness of U.S. exporters. It is likely that network associations influence and thus motivate members of Congress to take policy positions closer to the aid demands of those associations in order to show a willingness to get involved in social requests and pursue politics that support their agenda. Given that firms also create non-profit organizations as a channel for promoting their commercial interests, in empirical analysis, the distinction between NGOs and firms might not be an absolute one. A complete account of my coding scheme for aid constituency categories can be found in Appendix 1.

The two constituent groups clearly differ in terms of aid policy preferences which arises from their main activities in the aid industry. Development NGOs lobby Congress to earmark the aid budget in order to reflect their socioeconomic development concerns in aid policy (Bräutigam 2009, 15). Private enterprises petition aid agencies with the goal of promoting their own economic interests. The U.S. agriculture sector lobbies Congress to increase food aid in order to reduce domestic farm surpluses and thereby maintain the highest possible production and thus the highest possible profits (Lancaster 2008, 104). Testimonial statements given during legislative hearings by representatives of NGOs and firms represent their constituency interests in sectoral aid budgets. Development NGOs are expected to emphasize development and humanitarian aid issues in their testimonies, whereas private enterprises are expected to highlight commercial aid issues.

\section{Donor Ideology in Foreign Aid}

In many studies on foreign aid allocations, the left-right ideological distinction is identified in reference to ideas about the role of government in the redistribution of wealth. ${ }^{3}$ In this body of studies, left-wing governments based on socialist beliefs tend to redistribute wealth internationally in order to reduce global inequality, whereas right-wing governments based on conservative beliefs

\footnotetext{
${ }^{3}$ See Noël and Thérien (1995) and Thérien and Noel (2000).
} 
are less concerned about economic inequality and thus keep government intervention to a minimum to protect market freedom. ${ }^{4}$

By comparison, less studies elaborate either how or why parties of the Left and Right are incentivized to expand their distributional ideas on domestic issues to foreign aid policy, which requires transferring wealth from domestic taxpayers to recipient foreigners who do not vote in the donor country or support it in any way. Accordingly, the question as to why leftist parties are interested in achieving international solidarity instead of merely serving domestic beneficiaries without diverting limited resources abroad is barely considered. Rightist parties' preferences for aid are seen as directed at achieving diverse aid policy outcomes, depending on whether they prioritize minimizing government intervention in redistributing wealth globally or maximizing trade benefits in the international market by using aid as a foreign policy tool. ${ }^{5}$ This suggests that connections between issues are indeed not as tight as seen in the conventional representation of donor ideology. Leftist ideology is generally consistent in domestic issues based on the belief that governments should play a key role in addressing poverty and inequality, but this idea cannot be automatically applied to governments' distribution decisions on the international stage. In some cases, rightist ideology could rather bring about donor generosity, arguing for using aid to promote trade and infrastructure or to support a religious predisposition for solidarity, as in the case of the ChristianDemocratic parties. Therefore, it is likely that left-wing parties do not always want to engage in aid efforts, while, sometimes, right-wing parties want to commit to providing more development aid.

Relatively recently, studies exploring the linkage between donor ideology and foreign aid focus on a domestic electoral mechanism, suggesting that party leaders and governments may take aid issue positions as a way of reflecting general voters' preferences over aid (Paxton and Knack 2012; Greene and Licht 2018; Dietrich, Milner, and Slapin 2020). Exploring a government's relatively left or right position-taking for foreign aid in response to domestic demands is worthwhile in

\footnotetext{
${ }^{4}$ See also Dreher, Nunnenkamp, and Schmaljohann (2015) on how the relationship between donor political ideology and foreign aid has been addressed in the literature.

${ }^{5}$ For example, the literature on the aid policy choices of rightist governments falls into three categories: less aid (Lumsdaine 1993); more aid with a self-serving motivation (Round and Odedokun 2004; Fleck and Kilby 2006); and more aid with a compassionate motivation (Stokke 1996; Goldstein and Moss 2005).
} 
an endeavor to account for variations in the relationship between those two factors. Still, it can be questioned that aid policy is not salient enough to attract voters' attention and thus generate electoral support as a result. Milner and Tingley $(2010,2011)$ 's research notes that legislators make aid policy choices in Congress aligned with their own ideological preferences while considering the impact on their local constituencies, which raises important questions about the connection between voters and legislators. Building on this work, I contribute to the literature on the domestic mechanism of donors' aid decisions that underscores the importance of ideology by identifying the origins of mobilized interests that domestic constituencies have, and thereby demonstrating that individual legislators' broader application of ideology to aid policy is stimulated by constituent pressure. Therefore, the present study draws on insights from and advances both these research directions.

\section{Ideological Linkage: The Interaction between Legislators and Constituencies}

Legislators are expected to have ideological predispositions about government intervention in the economy that they have applied to domestic issues mostly. Leftist parties and politicians generally want to tackle poverty, inequality, and humanitarian disasters and promote development and humanitarian practices by adopting norms and policies aimed at reducing poverty and supporting socioeconomic growth. Rightist parties and politicians prefer to pursue export and investment interests such that their focus is advancing commercial concerns by supporting domestic firms' business activities in the international market.

In my framework, domestic constituent groups connect with legislators via ideology, whereby the groups attempt to strategically appeal to the latter to adopt their agendas. In giving testimony in the legislative process, domestic interest groups express their aid preferences. They also emphasize the larger segments of civil society they represent for which they often organize network associations that send witnesses to aid hearings to collectively speak for their common interests. Left-wing and right-wing legislators adopt the rationale behind aid expressed by the constituencies resonating

with their ideology. By responding to constituency demands on foreign aid, political parties and politicians demonstrate that their aid decisions take account of the views and interests of domestic 
taxpayers and show their willingness to get involved in social requests and, thus, to a certain extent justify the transfer of national capital to poorer states. Further, individual legislators are motivated to adopt a group's argument as their own in order to demonstrate loyalty to their constituencies. The broader community that both the NGO and firm constituencies represent position these groups as an attractive partner to politicians who are always seeking political support. Through interacting with a constituent group, legislators adopt its policy agenda and internalize its language as their own and thereby develop ideological preferences for aid. In this process, the legislators extend the application of their ideology, originally limited to domestic issues, to encompass foreign aid issues. As a result, I expect to find a correspondence between the word usage in the political statements of the constituencies and those of the legislators.

Accordingly, in comparison with right-wing policymakers, left-wing policymakers are more likely to respond to the demands of NGOs such that they mention more aid issues aligned with the NGOs in their political speeches and actions. Development NGOs emphasize socioeconomic development and humanitarian assistance in their testimonies in accordance with their dedication to eradicating world poverty and promoting human development in recipient countries (Lewis 2006); therefore, the agendas of these NGOs are more attractive to left-leaning legislators than are the agendas of private firms. Likewise, right-wing policymakers are more likely to respond to the demands of firms such that they mention more aid issues aligned with the agendas of the firms in their political speeches and actions in comparison with left-wing policymakers. Private firms emphasize commercial-sector aid in their testimonies as a way of creating and maintaining favorable market conditions in developing counties (Kim 2017); therefore, right-leaning legislators find private-sector agendas more attractive than those of the NGOs. On the basis of this account, the following testable hypotheses are presented:

Hypothesis 1. Development NGOs are more likely to mention development and humanitariansector aid issues than private enterprises in their testimonies.

Hypothesis 2. Private enterprises are more likely to mention commercial-sector aid issues than development NGOs in their testimonies. 
Hypothesis 3. Government-constituent policy congruence should be higher between development NGOs and left-leaning policymakers than between development NGOs and right-leaning policymakers.

Hypothesis 4. Government-constituent policy congruence should be higher between private enterprises and right-leaning policymakers than between private enterprises and left-leaning policymakers.

\section{Text Analysis to Measure Constituent Influence in Congress}

In my framework, legislators broaden the application of ideology to foreign aid agendas through interactions with domestic constituencies. Accordingly, legislators' aid policy positions correspond to their constituencies as a consequence of the groups' lobbying activities, which I expect to observe in a correspondence between the word usage of those two actors' political statements in regard to foreign aid. Text-as-data methods are useful for testing this theoretical expectation, not only by estimating the left-right positions of politicians and domestic groups but also by identifying the clusters of words that the actors use frequently and the extent to which these clusters overlap.

In the analysis, I employ unsupervised classification and scaling algorithms called Structural Topic Model (STM) and Wordfish in order to estimate the constituencies' and legislators' issue emphases and positions based on word frequency in their statements. In respect to the study's validity, quantitative text analysis has three advantages (Slapin and Proksch 2008, 708). First, this approach produces stable and reliable time-series estimates. Second, the text-as-data method does not require pre-existing categories to classify the text, which means latent topics can be discovered in the analytical process itself. Lastly, the technique literally processes all the words used in every document and calculates the proportion of each word in a given corpus, which improves the precision of the existing methodology. ${ }^{6}$

\footnotetext{
${ }^{6}$ Human coding is most powerful when multiple coders who are very knowledgeable about the project work in a coordinated way. However, several challenges to the validity of hand-coded outputs have been made in regard to processing a large volume of texts across multiple categories with heavy reliance on an individual coder's ideas, knowledge, and good sense (Quinn et al. 2010; Nowlin 2016).
} 


\section{Text Analysis in Political Science Research}

In political science research, text-as-data methods are a growing area of interest and in the context of legislative studies are used principally as a way to explore political processes and outcomes. In line with its recent wide availability, text has become a very important source of evidence in analyses of political processes. In particular, texts provide needed information about the policy preferences and positions of political actors at specific points in time (Klüver 2009, 536).

In respect to ideology and party politics, using bills and party manifestos as text data as an alternative measure to hand-coding outputs, e.g., the Comparative Manifesto Project (CMP/MARPOR), researchers have predicted roll-call votes in relation to legislator ideology (Kraft, Jain, and Rush 2016) and party positions and agenda (Diermeier et al. 2012; Barberá 2015; Preoţiuc-Pietro et al. 2017). The principal methods employed are ideological scaling to identify the positions of parties and legislators (Slapin and Proksch 2008; Rheault and Cochrane 2020) and classification to estimate the dimensions and salience in the language of legislators (Warntjen 2012; Grimmer 2013; Nowlin 2016). In many studies, the text-as-data approach focuses on the ideological preferences of politicians and parties. In contrast, there is a dearth of research on how the policy demands of domestic interest groups shape policy outcomes through the legislative process (Klüver 2009; Klüver 2015; Nowlin 2016). Nowlin (2016) identifies interest groups' positions on an environmental issue pertaining to Used Nuclear Fuel (UNF) from 1975 to 2012 by employing topic modeling techniques and found seven issue dimensions salient to the groups (e.g., "programmatic," "safety/regulation," and "science/technical"). By drawing on that study, I analyze the testimonial statements given by aid constituencies to find the prevalence of their issue dimensions. I then compare the results gained from the domestic groups with those of legislators using their Congressional speeches relating to foreign aid policy to estimate the extent of the policy congruence between these two actors. To this end, I use Wordfish to find the convergence/divergence of policy positions between political actors on a spectrum and to identify the semantic difference in word usage between the actors in relation

to the ideological stance of each. Slapin and Proksch (2008) applied the Wordfish method to the entire manifestoes of German parties and sub-samples of economic, societal, and foreign policies 
to estimate the ideological positions of German parties for the period of 1990 to 2005 . The authors found that leftist parties were more likely than rightist parties to use "women's movement," whereas rightist parties were more likely than leftist parties to use "business location" (p.716).

\section{Transforming Text to Data}

\section{The Corpus: U.S. Congressional Testimonies}

To create the text data, I used Proquest Congressional to download all the testimonial statements given by domestic constituent groups from 283 Congressional Hearings of 30 Senate and House committees in the period of 1980 to 2013 in which the search term foreign aid was found. ${ }^{78}$ The scope of my corpus was confined to non-departmental witnesses whose speeches directly address only foreign aid issues. From 1,837 returns retrieved from the website, I created a corpus of 1,472 testimonies given by 1,063 NGO witnesses and 409 firm witnesses. In Appendix 2, I provide a detailed report of the coding scheme I used to create the corpus and describe the coding process through which I converted the hearing transcripts from PDF format into TXT-files. ${ }^{9}$

I then pre-processed the words in each statement by converting them to lower case, maintaining only the word stems (through tokenization and stemming or lemmatization), and removing nonalpha characters (i.e., digits and special symbols) including punctuation, English stopwords, and organization names. I also removed procedural words that are used repeatedly in most Congressional hearings such as speaker, chairman/chairwoman, Senate, House, testimony, thank, and committee. Excluding these common words makes it easier to detect substantively significant words in an analysis by eliminating words that would not contribute to it. In addition, I removed words that

\footnotetext{
${ }^{7}$ Foreign aid is one of the auto-generated search terms on the Proquest Congressional website. This category incorporates a variety of terminologies that refer to foreign aid and its sub-categories such as development assistance, foreign assistance, economic aid, military aid, and food aid.

8 Table A5 presents the list of committees in the sample that held the foreign aid hearings.

${ }^{9}$ In regard to the focal period of this study, given that the U.S. government began to provide grants to domestic NGOs in the early 1950s, I had originally intended to collect testimonial statements from that time onwards. However, due to the poor quality of the scanned PDF files for these early records, the converted TXT files turned out to be messy outputs. Eventually, I set 1980 as the start year of the text data for two reasons: First, the PDF-TXT conversion produces very few or even no errors from 1980 onwards due to the high resolution of the PDF files. Second, the participation of domestic interest groups in Congressional hearings as non-departmental witnesses increased from around the late 1970 s to the early 1980 s at which time multiple panels started to be organized under a single hearing agenda.
} 
were highly unlikely to be associated with any topics relevant to the focal topic, i.e., words that appeared in less than 5 percent of the documents in the corpus, to prevent unwanted noise in the models. Lastly, I considered bigrams in the text analysis. ${ }^{10}$

Eventually, I created my original text data with rows presenting testimonial statements made by constituent groups and columns identifying the hearings at which the statements were made. For example, the dataset includes variables such as citation number (i.e., a unique identifier for each hearing case), witness name, group name, hearing title and date, committee name and Senate/House dummy, and lastly NGO/Firm dummy, which is a prerequisite for classification. Given that multiple sessions are often arranged in one hearing for various groups to testify, a couple of testimonies are drawn from a single hearing case and, therefore, have the same citation numbers in the dataset. To code an NGO/Firm dummy, i.e., whether each statement was made by an NGO or Firm witness, I used the part of the speech from the testimony in which the individual witness introduces the organization that he or she represents and searched the name of the organization in order to determine the organization's activities from its website if the organization did, in fact, have one. As reported in Table 1, after the documents were pre-processed, the average number of words per statement was 563.15, ranging from the minimum of 40 to the maximum of 3,199 . On average, 43.29 statements were made by constituent groups every year, with 1994 as the year with the highest number of statements (111) of all the years included in the analysis. The last two columns present the summary statistics for the number of aid hearings held in the Senate and the House each year during the focal period of this study.

Next, Figure 1 provides an overview of the constituent groups included in the sample and their loquaciousness in terms of mean token frequency. ${ }^{11}$ Figure 1 presents information about the corpus to be analyzed. First, on average, more NGOs than firms testified in aid hearings during the focal period. Second, the number of individual witnesses for NGOs and firms increased until 1996. But the numbers largely declined in the early 2000s. As presented in the second plot, the number of

\footnotetext{
${ }^{10}$ For example, White House is an example of a bigram that has a completely different meaning from White and House considered separately.

11 Tokens are individual units of meaning created by breaking sentences into smaller chunks. In many cases, tokens can be referred to as words or terms.
} 
Table 1: Descriptive Statistics for the Corpus, 1980-2013.

\begin{tabular}{lrrrr}
\hline \hline & Words Count per Doc & Documents Count by Year & Hearings in House by Year & Hearings in Senate by Year \\
\hline Mean & 563.15 & 43.29 & 32.12 & 13.43 \\
Std & 420.86 & 27.04 & 17.83 & 11.22 \\
Min & 40.00 & 3.00 & 4.00 & 1.00 \\
$25 \%$ & 314.00 & 21.50 & 19.00 & 4.25 \\
$50 \%$ & 440.00 & 38.50 & 28.00 & 9.50 \\
$75 \%$ & 660.50 & 53.75 & 42.00 & 19.00 \\
Max & $3,199.00$ & 111.00 & 79.00 & 38.00 \\
\hline
\end{tabular}
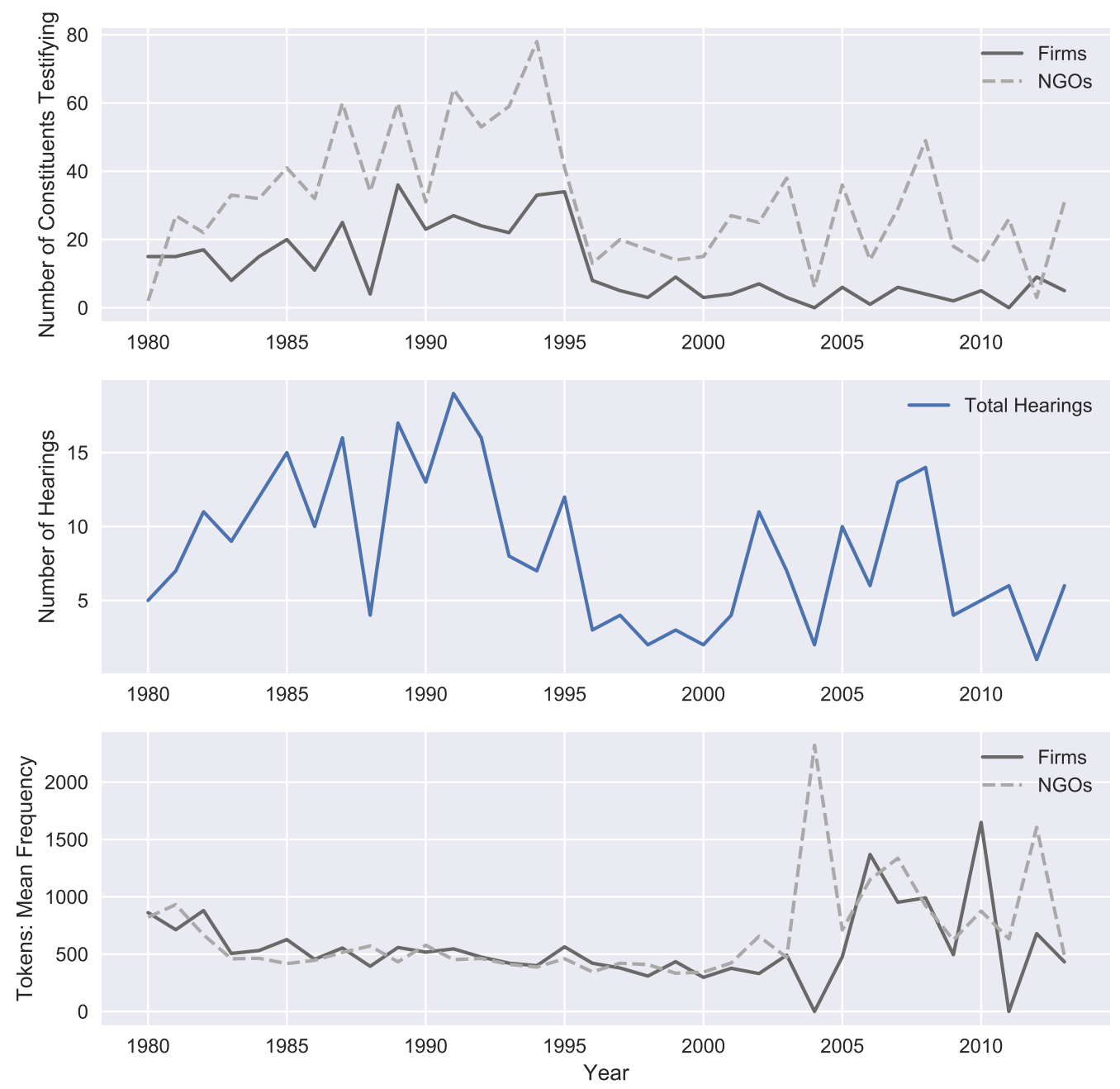

Figure 1: Number of Constituent Witnesses and Mean Token Frequency per Document, 1980-2013.

witnesses tended to vary in line with the total number of hearings across the years. In other words, the number of hearings related to foreign aid largely decreased from the late 1990s to the early 2000s and this downward trend more or less continued from that point onwards. In contrast, the 
length of the witnesses' speeches increased to a large extent around the mid-2000s, as shown in the last plot. This suggests that testimonies from a variety of groups became incorporated as multiple sessions in a single hearing case.

\section{Text-As-Data: Analyses}

\section{Issue Salience of NGO and Firm Constituencies}

To test Hypotheses 1 and 2 on the NGOs' and firms' policy preferences over sectoral aid, I estimated the Structural Topic Models (STM) on the corpus of aid appropriations hearings. ${ }^{12}$ The final models fit six topic dimensions for the NGO constituency and five topic dimensions for the firm constituency. The 20 most common words found in each topical category are presented in Figure 2. I also measured the difference in topical prevalence between the NGO and firm constituencies within a particular topic by testing the models on the entire corpus with the constituency typespecified covariate to identify a single issue spectrum on which both groups of constituencies express divergent issue positions to advocate for their policy preferences. The final model clustered eight topic dimensions. The topics and the top 20 words for each cluster appear in Table A6. I check the models' robustness given the number of topics generated in respect to the semantic validity of the topic dimensions in Appendix 3. ${ }^{13}$

In Figure 2, the first set of topic model categories shows that NGOs' biggest concerns in their testimonies related to foreign aid are the development and humanitarian sectors, as shown in their word emphasis on (a) refuge/humanitarian: refugee, peace, food, and emergency; (b) health: vitamin, vaccine, disease, child, survival, and deficiency; and (c) military vs. development aid: security, development assistance, economic support, balance, and sustainable development. While the firms also address (a) health issues in their testimonies, as shown in their word emphasis

\footnotetext{
${ }^{12}$ I used the stm package in $\mathrm{R}$ to identify the number of topics and estimate parameters. I held the time effect constant by including the integer variable of HEARING DATE in the equation and thereby allowing for it to have a non-linear relationship in the topic estimation stage. In Figure 3, I included the CONSTITUENT TYPE variable as a content covariate.

${ }^{13}$ To make sure that the topic categories would fully represent their subset documents as intended, I pulled out and looked at the set of sample documents that are most highly associated with each topic to check whether the main topic of each document matched the meta-topic generated by the word clusters. I then cross-checked the result in cooperation with other human coders.
} 


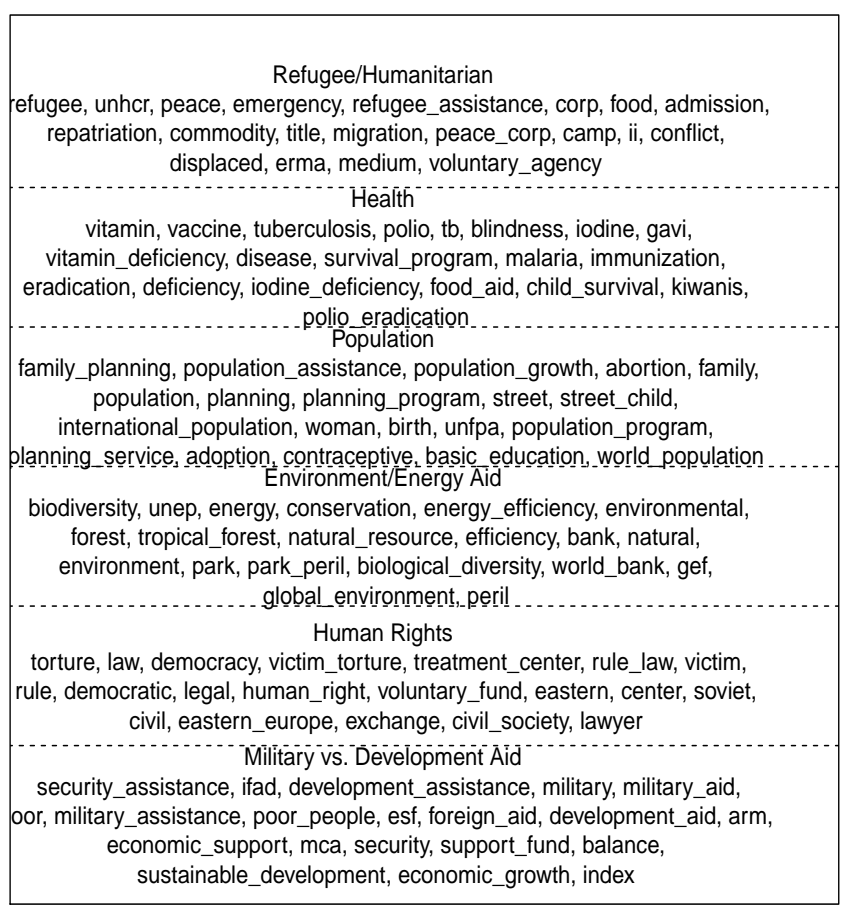

\begin{tabular}{|c|}
\hline $\begin{array}{l}\text { Aid for US Interests } \\
\text { russian, food, foreign_assistance, economic_development, russia, economic, } \\
\text { former, commission, stability, regulatory, economy, corporation, america, } \\
\text { property, foreign_aid, agriculture, democracy, nation, recipient, claim }\end{array}$ \\
\hline $\begin{array}{l}\text { Export and Market Promotion } \\
\text { eximbank, mpp, exim, export, competitive, promotion, machinery, exporter, } \\
\text { financing, boeing, sale, firm, competition, export_import, loan_program, } \\
\text { import_bank, airbus, promotion_program, compete, exim_bank }\end{array}$ \\
\hline $\begin{array}{l}\text { Environment/Energy Aid } \\
\text { energy, renewable, renewable_energy, energy_efficiency, efficiency, } \\
\text { energy_program, diesel, wind, technology, clean, solar, environmental, report, } \\
\text { language, family, utility, mission, office_energy, renewables, clean_energy }\end{array}$ \\
\hline $\begin{array}{l}\text { Credit Union } \\
\text { credit_union, cooperative, rural, union, pvos, dairy, farmer, organization, } \\
\text { housing, poland, voluntary, credit, eastern, technical, private_voluntary, } \\
\text { technical_assistance, association, eastern_europe, telephone, saving }\end{array}$ \\
\hline $\begin{array}{l}\text { Health } \\
\text { think, going, cite, lot, woman, say, ngo, child, thing, vaccine, back, really, } \\
\text { getting, look, feel, go, day, military, disease, got }\end{array}$ \\
\hline
\end{tabular}

Figure 2: 20 Most Common Words from Topic Model Categories (NGOs-Firms).

on vaccine and disease with a focus on woman and child and in consideration of ngo, the firm constituency is generally interested in the commercial sector, by promoting (b) export and market: eximbank, export, competitive, promotion, exporter, firm, and loan program and advocating for aid budgets to advance the (d) U.S. economic interests in the global market: e.g., food, economic, regulatory, agriculture, and corporation, as shown in the second set of topic model categories. The following paragraphs serve as typical examples:

[N] "Now what my agency believes is that we must do more to meet basic human needs so that people whether they be in Asia Africa or Latin America are given the chance to enter the mainstream of development" (Frederick W. Devine, Care, 26 July 1983).

[F] "The primary thrust of the ACA [Agriculture Council of America] program is to carry forward in the last half of the decade of the multiple programs of humanitarian food relief economic development and commercial market building that made possible the increase in U.S. agricultural exports" (Orville L. Freeman, Agriculture Council of America, 31 March 1987). 


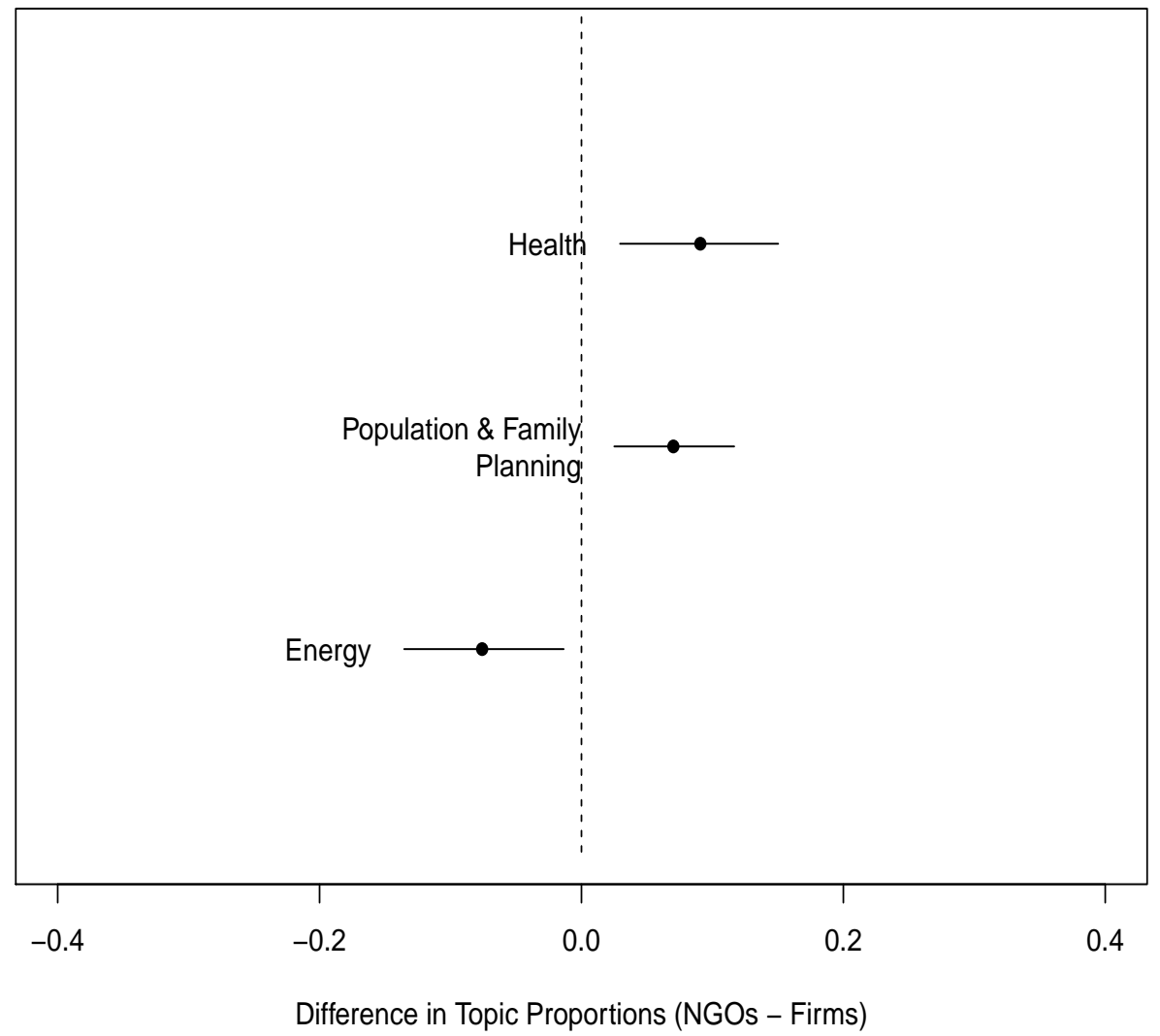

Figure 3: Topical Prevalence between NGOs and Firms.

Next, the topic model results showing the difference in topical prevalence between the NGO and firm constituencies is presented in Figure 3. The results suggest that representatives of NGOs are more likely to address energy-related topics in their testimonies, whereas representatives of private enterprises are more likely to discuss health- and population-related topics in their testimonies. In the case of energy issues, the word usage in the statements of the constituencies in Figure 4 suggests that the NGOs emphasized environmental conservation from aid projects in the energy sector, which are mostly awarded through the Multilateral Development Banks (MDBs)' loan programs such as the World Bank. On the other hand, the firms emphasized their interest in securing aid contracts and funding for technology, energy efficiency, and renewable energy programs. In sum, the NGO and firm constituencies indicate a clear divergence in terms of their issue positions for energy aid. 
The NGOs' and firms' use of vocabularies in respect to health and population topics appears in Figure A9.

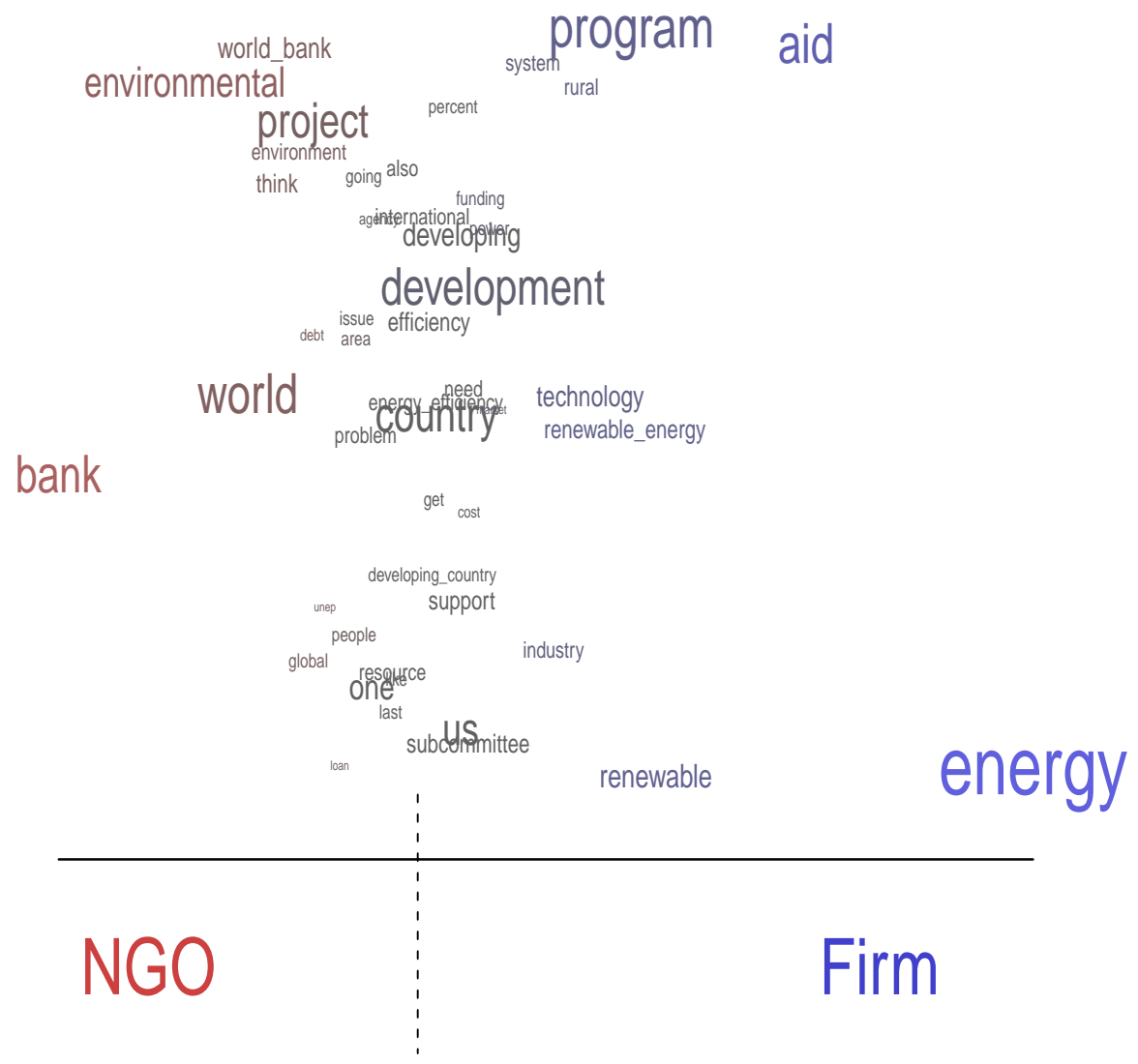

Figure 4: Topical Content over Energy Aid between NGOs and Firms.

\section{Policy Congruence between Constituencies and Legislators}

To test Hypotheses 3 and 4, I employed Wordfish to examine the extent of policy congruence between donor governments and aid constituencies in accordance with their ideological preferences. One important condition necessary for this analysis is that individual actors should be located on the same policy spectrum. Based on the previous topic model results, I decided to focus on an issue of energy aid for my Wordfish model which is salient to both the NGO and firm constituencies. Given that the main reason for domestic interest groups to testify at hearings is to get their policy demands reflected in legislative outcomes, each group's policy stance on the given issue is likely to be clearly revealed in the testimony. For individual legislators, I gathered and analyzed their 
Congressional speeches. To compare the positions between legislators and constituents on energy aid, I applied the same key words used to create the corpus for the constituent testimonies to the floor speeches, for the computability of the text data. I collected the texts from the Congressional Record Daily Edition, which enabled me to find individual politician's speeches under a single topic. ${ }^{14}$ Congressional speeches are a good source of data for testing my hypotheses, as those speeches are not critically related to their party's interests, which means politicians are likely to reveal their own preferences in these statements (Cutrone and Fordham 2010, 641).

As witnesses are invited to testify by legislators, it is reasonable to ask whether the latter had already established their aid preferences and selected the witnesses to support these. However, it must be highlighted that most witnesses in the corpus for energy aid hearings appeared before the committees on foreign aid appropriations or the committees on foreign affairs in respect to authorizing foreign aid appropriations. The list of the witnesses in the energy aid hearings corpus can be found in Table A7. The results gained from the appropriation hearings are unlike other types of hearings in three principal ways: First, the list of witnesses appearing before the committees on foreign aid appropriations does not change much across the years. Second, the witnesses' testimonial statements focus mainly on the sectoral aid budgets that the organizations they represent are interested in. Third, the rule whereby a written statement of the testimony is provided in advance of the witness's appearance does not apply to any witnesses in the overall budget hearings. Similarly, the hearings before the committees on foreign affairs in this sample were held to authorize a given year's aid appropriations in regard to the U.S. voluntary contributions to international organizations. This line of discussion suggests that the selection of witnesses and their statements are unlikely to be significantly affected by individual politicians' preferences in the case of the sub-sample of energy aid hearings.

\footnotetext{
14 Out of 185 returns on foreign aid found in the whole period (no time restriction applied), I used the search terms including energy, oil, and resources and then read all the pre-selected speeches to exclude irrelevant cases, as I did for the corpus on constituents' testimonies.
} 


\section{Spatial Locations over Energy Aid}

Based on their speeches, I first located both the NGO and firm constituencies (Figure 5) and Democrats and Republicans (Figure 6) on a single dimension for energy aid to estimate the policy positions of constituent groups and legislators. Figure 5 shows the relative positions of five NGOs and five firms in their testimonies relating to energy aid. ${ }^{15}$ A majority of the groups representing the NGO constituency are located closer to the left end of the policy scale, whereas a majority of the groups representing the firm constituency are located closer to the right end of the scale. The constituents' locations suggest that NGOs and firms tend to diverge on a single policy space.

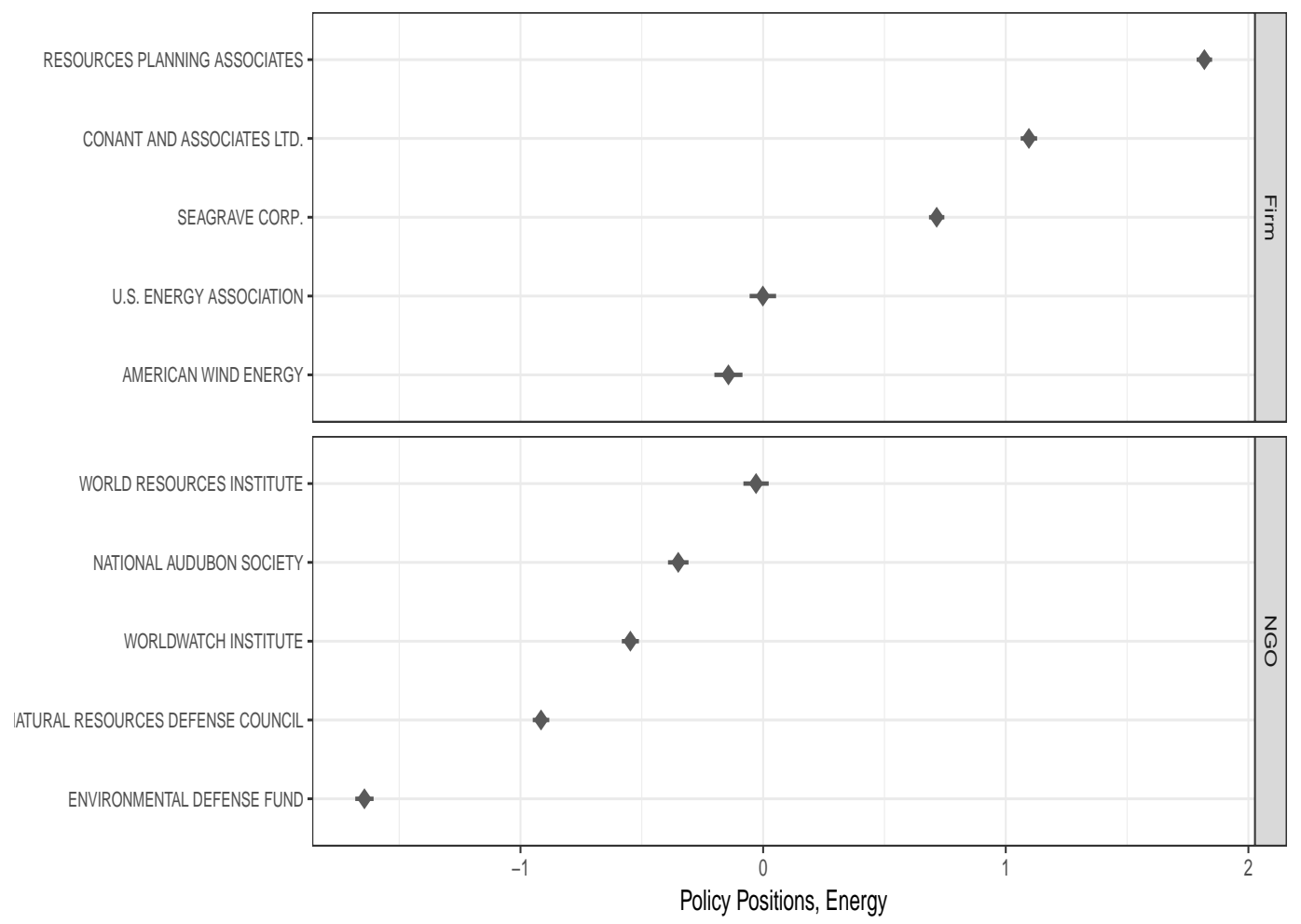

Figure 5: Energy Aid Positions of 5 NGOs and 5 Firms Testifying at the Relevant Hearings.

Figure 6 presents the policy positions of four Democrats and two Republicans in their floor speeches relating to energy aid. Corresponding to the constituent locations as presented in Figure 5, the speakers from the Democratic party are located closer to the left end of the policy scale, whereas

\footnotetext{
${ }^{15}$ To make sure that all testimonies featured a discussion of the topic of interest, only documents with the keywords energy, oil, and resource were included. I then read all the pre-selected documents and excluded those in which energy did not constitute the main issue.
} 
the speakers from the Republican party are located closer to the right end of the scale. Overall, the results support my argument that government-constituent policy congruence is likely to be higher between development NGOs and left-leaning policymakers than between development NGOs and right-leaning policymakers, and vice-versa for policy congruence between private enterprises and left-leaning and right-leaning policymakers.

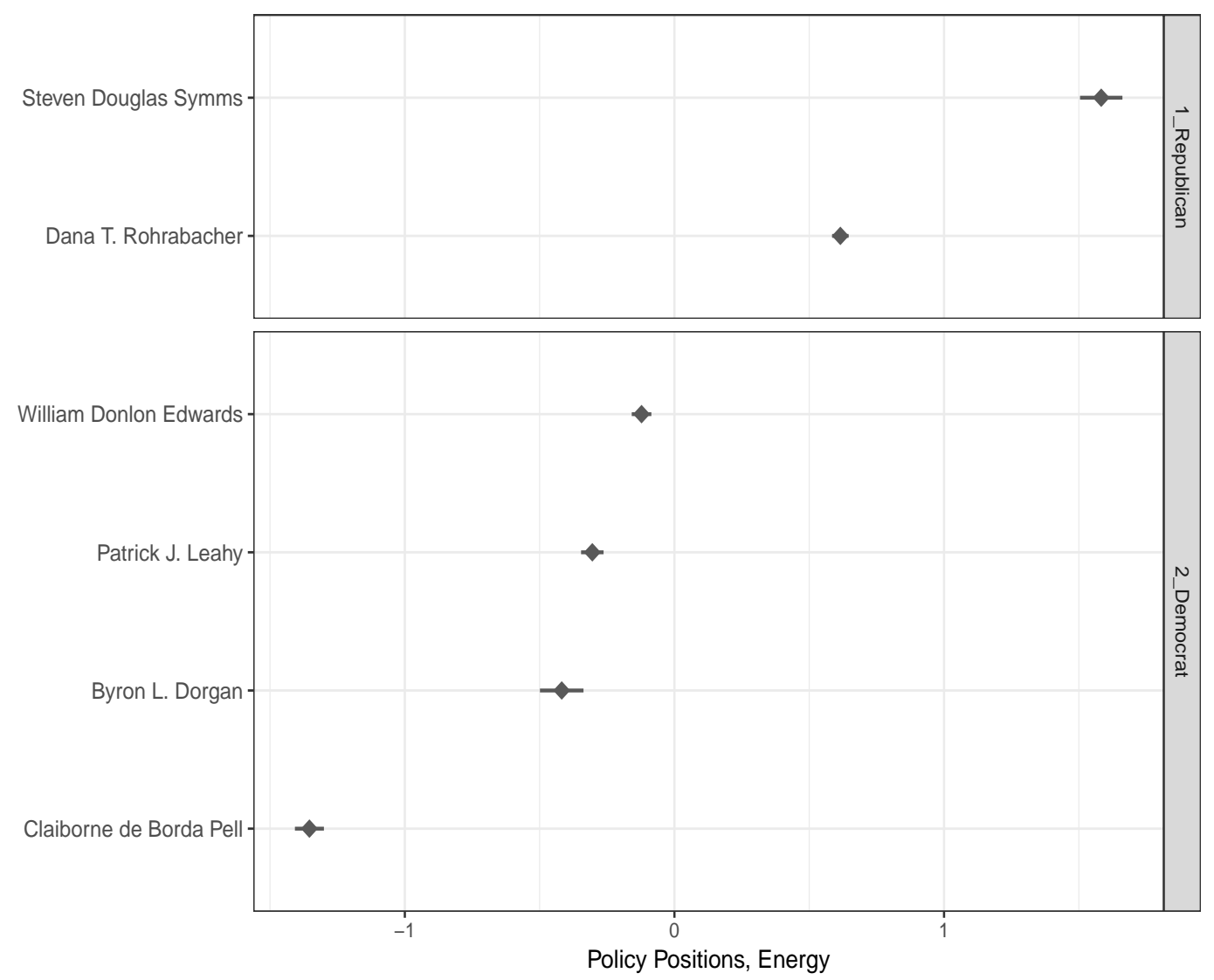

Figure 6: Energy Aid Positions of 4 Democrats and 2 Republicans in the Relevant Floor Speeches.

In Table 2, I reported the list of Congressional energy aid speakers in the corpus with their DWNOMINATE scores published by the Congressional Roll-Call Votes Database (Lewis et al. 2019). Although the ideology scores of individual politicians in terms of economic liberalism-conservatism are not in precisely direct proportion to their energy aid positions as shown in Figure 6, these six politicians generally have a relatively stronger ideological stance, indicating a more liberal or conservative position than the median scores for the left and right. 
Table 2: List of Congressional Energy Aid Speakers.

\begin{tabular}{lllrr}
\hline \hline & Members of Congress & & Congress Sessions & DW-Nominate Scores (1st dim) \\
\hline 1 & Steven Douglas Symms & R-ID & $99-1$ & 0.687 \\
2 & Dana T. Rohrabacher & R-CA & $102-1$ & 0.626 \\
3 & Claiborne de Borda Pell & D-RI & $99-1$ & -0.332 \\
4 & Byron L. Dorgan & D-ND & $101-2$ & -0.267 \\
5 & Patrick J. Leahy & D-VT & $101-2$ & -0.36 \\
6 & William Donlon Edwards & D-CA & $102-2$ & -0.599 \\
\hline
\end{tabular}

\section{Semantic Congruence over Energy Aid}

To demonstrate that the convergence in terms of the locations between aid constituencies and legislators is also semantically meaningful, I estimated the clusters of words at each end of the left-right spectrum. Table 3 presents the lists of words with the highest word weights on the left end (negative) and the right end (positive) of the single dimension for domestic constituencies. Groups representing the NGO constituency, clustered at the left side of the spectrum as shown in Figure 5, are more likely to use words such as world bank, dam, environmental clearance, environmental impact, and resettlement in their testimonies. On the other hand, groups representing the firm constituency, located closer to the right end of the spectrum, used the words exploration, oil market, oil discovered, and frontier. In short, the set of words for the NGOs suggest the notion of "pro-environmental regulation," with an emphasis on protecting the environment and indigenous people and preserving natural resources in areas likely to be affected by aid projects, whereas the set of words reveals for the firms suggest the notion of "anti-environmental regulation," with an emphasis on increasing access to energy sources, as demonstrated in the following examples:

[N] "The national environmental organizations that I represent today think that a complete reappraisal by the World Bank of the Sardar Sarovar Dam project is the only way that the bank's continued participation in this scheme can be justified. It's a large energy and coalmining development project in the Singrauli area in India. What is wrong is quite simple. Tens of thousands of people who once had a traditional agricultural subsistence way of life on the World Bank project sites have been forcibly displaced with little or no compensation" (Bruce M. Rich, Environmental Defense Fund, 02 April 1987). 
Table 3: Top 20 Word Weights in Energy Aid: NGO Constituents and Firm Constituents.

\begin{tabular}{lll}
\hline \hline & Negative Top 20 Words & Positive Top 20 Words \\
\hline 1 & world bank & exploration \\
2 & american development & offshore \\
3 & inter american & host government \\
4 & indian & non-opec \\
5 & inter & world oil \\
6 & dam & non-opec developing \\
7 & bank project & oil market \\
8 & environmental community & synthetic \\
9 & road & geologic \\
10 & director & according \\
11 & development bank & partially \\
12 & environmental clearance & oil discovered \\
13 & community group & proposal \\
14 & environmental impact & frontier \\
15 & multilateral bank & hole \\
16 & letter & giant \\
17 & northwest & exxon \\
18 & singrauli & onshore \\
19 & resettlement & frontier area \\
20 & clearance & new oil \\
\hline
\end{tabular}

[F] "From a national security viewpoint, it is clear that development of new domestic energy supplies is preferable to newly identified foreign supplies. [...] I believe that both programs are needed more domestic energy supplies for our own national security where we might pay a premium of as much as per barrel more than conventional oil plus more non-OPEC oil to challenge the worldwide economic power of the cartel" (Arnold E. Safer, Resources Planning Associates, 05 February 1980).

It is interesting that the "American Wind Energy" from the private sector is located slightly closer to the left dimension in Figure 5. The American Wind Energy Association is the umbrella organization established to promote the interests of the U.S. wind energy industry. Given its testimony as presented below, this network body seems focused on appealing to the government for funds to support the renewable energy business. That is, this group highlighted its concern for environmental impacts, e.g., "clean energy generation," which presumably positions it a little bit closer to the NGO side. 
[F] "Both use donor aid programs to support their independent industry very aggressively and it gives them a significant competitive advantage. U.S. AID, on the other hand, once again, as we have stated last year and the year before, has no major renewable energy projects in the entire AID mission structure. [...] Renewable energy technologies have achieved a commercial viabilities threshold that often has been cited by some of the vested interests as a reason to ignore the promise of clean energy generation" (Michael L. Marvin, American Wind Energy, 01 May 1992).

Table 4: Top 20 Word Weights in Energy Aid: Democrats and Republicans.

\begin{tabular}{lll}
\hline \hline & Negative Top 20 Words & Positive Top 20 Words \\
\hline 1 & amendment & angola \\
2 & biological & cuban \\
3 & wildlife & surrogate \\
4 & natural & unita \\
5 & ecosystem & angolan \\
6 & habitat & moscow \\
7 & biological diversity & region \\
8 & wildlife habitat & platinum \\
9 & diversity & manganese \\
10 & plant & chrome \\
11 & protect & cobalt \\
12 & policy institute & southern africa \\
13 & environmental policy & occupation \\
14 & term agreement & tank \\
15 & long term & aircraft \\
16 & enter long & popular \\
17 & protect wildlife & peace \\
18 & conserve biological & succeed \\
19 & hearing & gold \\
20 & institute & ferrochrome \\
\hline
\end{tabular}

In Table 4, liberal speakers are more likely to use words such as ecosystem, biological diversity, protect, and environmental policy in their floor speeches, whereas conservative speakers are more likely to use words focused on natural resources as expected aid benefits such as platinum, manganese, chrome, cobalt, and gold. In short, the sets of word weights support Hypotheses 3 and 4 in regard to policy congruence for the left-right ideological divide between domestic constituencies 
and policymakers: i.e., the left generally focuses on protecting the environment and bio-diversity of recipient countries implementing energy aid projects, whereas the right generally focuses on discovering energy and natural resources in recipient countries as a means of fulfilling domestic demands. The following examples demonstrate this line of argument:

[D] "The extinctions projected in the coming decades will be largely due to human activities. They will occur on a scale that render natural biological extinction trivial by comparison. This loss of species and ecosystems due to human activities is resulting in the progressive impoverishment of the Earth's biological systems. This in turn reduces the ability of natural systems to support human populations" (Claiborne de Borda Pell, D-RI, 99th Congress, 1st Session).

[R] "We have seen opposition from liberal circles in the United States to development of nuclear energy to the point that other nations have raced ahead of us in providing their countries with safe and clean nuclear energy to challenge the worldwide economic power of the cartel" (Dana T. Rohrabacher, R-CA, 102th Congress, 1st Session).

\section{Discussion}

It can be reasonably questioned that some of the political speeches made by policymakers regardless of their ideological orientation may be made in direct response to exogenous events relevant to foreign aid. The best example suggesting the influence of global events on donors' domestic politics on aid is the Millennium Development Goals (MDGs) adopted by the United Nations in 2000. ${ }^{16}$ The international community launched a campaign focused on MDGs in order to collectively eradicate extreme hunger, halt the spread of HIV/AIDS, improve maternal health and reduce child mortality, and advance toward universal primary education. ${ }^{17}$ The MDGs were

\footnotetext{
${ }^{16}$ After the target date of 2015, the Sustainable Development Goals (SDGs) were endorsed as the successor of the MDGs.

${ }^{17}$ In addition to the emergence of the MDGs as a global norm, some major global trends have influenced donors' domestic politics in regard to aid over the last 70 years of aid history. In the early 1970 s, Western donors first committed to providing 0.7 percent of their gross national income on foreign aid (ODA/GNI). The Washington Consensus that emerged along with globalization in the 1980s and 1990s led donors to make their aid conditional by requiring recipients to make structural adjustments and pursue market liberalization.
} 
established as an institutional vehicle to drive donor states to adopt a position according to which poverty is morally unacceptable and to internalize poverty reduction as a primary goal in their aid-giving (Fukuda-Parr and Hulme 2011).

I expect that global norms and standards are internalized in donors' aid practices, activated by the NGOs and firms respective lobbying activities with legislators. Both constituencies are expected to use such international events to advocate for their policy preferences. For example, it is likely that both groups promote the MDGs by putting pressure on governments to uphold global standards thereby increasing the sectoral aid budgets for their area of interest, i.e., directly related to the socioeconomic development of recipient countries. For example, the topic proportions in Figure A10 in Appendix 4 suggest that the salience of the "health" topic category has increased in both the NGOs' and firms' testimonies over time and especially after the adoption of the MDGs in 2000.

\section{Conclusion}

In this paper, I explored how constituent interests shape donors' aid decisions in Congress. I argued that legislators' application of ideology, originally limited to domestic policies, extends to foreign aid policy through interactions with domestic constituencies. I expected to observe that a correspondence between the constituencies and the legislators in terms of word usage occurs in their speeches in Congress, suggesting not only that the aid policy agendas of left- and right-leaning politicians are primed by their domestic constituencies, but also that legislators develop ideological preferences for aid through interacting with their constituencies. To test my arguments, I applied quantitative text analysis methods to testimonial statements made by domestic interest groups in the U.S. Congressional Hearings for foreign aid and floor speeches of left- and right-leaning legislators relating to foreign aid. I, therefore, identified not only the issue emphasis and positions of the NGO and firm constituencies, but also the policy congruence between the constituencies and legislators. I found significant evidence to show that government-constituent policy congruence is higher between development NGOs and left-leaning policymakers than between development NGOs and right-leaning policymakers. I also found that government-constituent policy congruence is higher 
between private enterprises and right-leaning policymakers than between private enterprises and left-leaning policymakers.

This paper advances the literature on donor ideology and foreign aid by identifying the process through which ideology influences donors' aid decisions. In my framework, constituent pressure from domestic groups is a principal determinant of donors' foreign aid decisions through left-right ideological ties between legislators and constituencies. Legislators are moved by both groups' pressure in defining their aid policy preferences. My analysis, with the case of the US, contributes to a better understanding of the connections between donors' ideological propensities and their aid decisions. Further, the findings demonstrate that testimonial statements at congressional hearings are a useful source of data in measuring political actors' policy positions and issue salience based on their word usage.

One limitation of this study is that my self-coded corpus is only available from 1980 onwards, where domestic constituencies surrounding foreign aid are already well-established, and, therefore, the present study cannot observe the influence of those constituencies initially formed. In future research undertaken to advance the field's understanding of how domestic politics on aid shape donors' aid decisions, more diversified text data sources should be used to capture the policy preferences of political actors.

On a related note, I think emerging donors who have recently started to provide aid would be a good place to test my theoretical expectations given that there are unlikely to have fully developed aid constituencies domestically. Unlike the US, domestic interest groups in these donor countries are newly engaged in the legislative process. Therefore, we might be able to observe a more extensive relationship between legislators and constituent groups in emerging donor countries than is the case in the US. Future work in this area can be expected to improve our understanding of emerging donors' aid decisions, particularly given that the standard account for the effects of partisan ideology focuses almost exclusively on traditional donors. In this context, my study provides a substantive reference for future research by exploring the ways in which domestic interests engage in the legislative process of donor states by connecting with legislators through ideology. 


\section{References}

Barberá, Pablo. 2015. Birds of the Same Feather Tweet Together: Bayesian Ideal Point Estimation Using Twitter Data. Political Analysis 23 (1):76--91.

Blei, David M. 2012. Probabilistic Topic Models. Communications of the ACM 55 (4):77-84.

Bräutigam, Deborah. 2009. The Dragon's Gift: The Real Story of China in Africa. Oxford: Oxford University Press.

Brech, Viktor, and Niklas Potrafke. 2014. Donor Ideology and Types of Foreign Aid. Journal of Comparative Economics 42 (1):61-75.

Cutrone, Ellen A., and Benjamin O. Fordham. 2010. Commerce and Imagination: The Sources of Concern about International Human Rights in the US Congress. International Studies Quarterly $54(3): 633-55$.

Diermeier, Daniel, Jean-François Godbout, Bei Yu, and Stefan Kaufmann. 2012. Language and Ideology in Congress. British Journal of Political Science 31-55.

Dietrich, Simone, Helen V. Milner, and Jonathan B. Slapin. 2020. From Text to Political Positions on Foreign Aid: Analysis of Aid Mentions in Party Manifestos from 1960 to 2015. International Studies Quarterly 64 (4):980-990.

Dreher, Axel, and Andreas Fuchs. 2015. Rogue Aid? An Empirical Analysis of China's Aid Allocation. Canadian Journal of Economics 48 (3):988-1023.

Dreher, Axel, Andreas Fuchs, and Peter Nunnenkamp. 2013. New Donors. International Interactions 39 (3):402-15.

Dreher, Axel, Peter Nunnenkamp, and Maya Schmaljohann. 2015. The Allocation of German Aid: Self-Interest and Government Ideology. Economics \& Politics 27 (1):160-84.

Dreher, Axel, Peter Nunnenkamp, and Rainer Thiele. 2011. Are 'New’ Donors Different? Comparing the Allocation of Bilateral Aid between NonDAC and DAC Donor Countries. World Development 39 (11):1950-68.

Fleck, Robert K., and Christopher Kilby. 2006. How Do Political Changes Influence US Bilateral Aid Allocations? Evidence from Panel Data. Review of Development Economics 10 (2):210-23. 
Fukuda-Parr, Sakiko, and David Hulme. 2011. International Norm Dynamics and the "End of Poverty": Understanding the Millennium Development Goals. Global Governance: A Review of Multilateralism and International Organizations 17 (1):17-36.

Goldstein, Markus P., and Todd J. Moss. 2005. Compassionate Conservatives or Conservative Compassionates? US Political Parties and Bilateral Foreign Assistance to Africa. Journal of Development Studies 41(7):1288-1302.

Greene, Zachary D., and Amanda A. Licht. 2018. Domestic Politics and Changes in Foreign Aid Allocation: The Role of Party Preferences. Political Research Quarterly 71 (2):284-301.

Grimmer, Justin. 2013. Appropriators Not Position Takers: The Distorting Effects of Electoral Incentives on Congressional Representation. American Journal of Political Science 57 (3):62442.

Grimmer, Justin, and Brandon M. Stewart. 2013. Text As Data: The Promise and Pitfalls of Automatic Content Analysis Methods for Political Texts. Political Analysis 21 (3):267-97.

Kim, Youngwan. 2017. How NGOs Influence US Foreign Aid Allocations. Foreign Policy Analysis $13(1): 112-32$.

Klüver, Heike. 2009. Measuring Interest Group Influence Using Quantitative Text Analysis. European Union Politics 10 (4):535-49.

Klüver, Heike. 2015. The Promises of Quantitative Text Analysis in Interest Group Research: A Reply to Bunea and Ibenskas. European Union Politics 16 (3):456-66.

Kraft, Peter, Hirsh Jain, and Alexander M. Rush. 2016. An Embedding Model for Predicting Rollcall Votes. In Proceedings of the 2016 Conference on Empirical Methods in Natural Language Processing 2066-70.

Lancaster, Carol. 2008. Foreign Aid: Diplomacy, Development, Domestic Politics. Chicago: University of Chicago Press.

Lauderdale, Benjamin E., and Alexander Herzog. 2016. Measuring Political Positions from Legislative Speech. Political Analysis 374-94. 
Lewis, David. 2006. The Management of Non-governmental Development Organizations. Milton Park, Abingdon, Oxon: Routledge.

Lewis, Jeffrey B., Keith Poole, Howard Rosenthal, Adam Boche, Aaron Rudkin, and Luke Sonnet. 2019. Voteview: Congressional Roll-call Votes Database. Available at <https://voteview.com>. Accessed 1 Februrary 2021.

Lumsdaine, David Halloran. 1993. Moral Vision in International Politics: The Foreign Aid Regime, 1949-1989. Princeton University Press.

Milner, Helen V., and Dustin H. Tingley. 2010. The Political Economy of US Foreign Aid: American Legislators and the Domestic Politics of Aid. Economics \& Politics 22 (2):200-32.

Milner, Helen V., and Dustin H. Tingley. 2011. Who Supports Global Economic Engagement? The Sources of Preferences in American Foreign Economic Policy. International Organization 65 (1):37-68.

Noël, Alain, and Jean-Philippe Thérien. 1995. From Domestic to International Justice: The Welfare State and Foreign Aid. International Organization 523-553.

Nowlin, Matthew C. 2016. Modeling Issue Definitions Using Quantitative Text Analysis. Policy Studies Journal 44 (3):309-31.

Paxton, Pamela, and Stephen Knack. 2012. Individual and Country-level Factors Affecting Support for Foreign Aid. International Political Science Review 33 (2):171-192.

Preoţiuc-Pietro, Daniel, Ye Liu, Daniel Hopkins, and Lyle Ungar. 2017. Beyond Binary Labels: Political Ideology Prediction of Twitter Users. In Proceedings of the 55th Annual Meeting of the Association for Computational Linguistics (Volume 1: Long Papers), 729-40.

Proksch, Sven-Oliver, and Jonathan B. Slapin. 2008. WORDFISH: Scaling Software for Estimating Political Positions from Texts.” Version 1:323-44.

Quinn, Kevin M., Burt L. Monroe, Michael Colaresi, Michael H. Crespin, and Dragomir R. Radev. 2010. How to Analyze Political Attention with Minimal Assumptions and Costs. American Journal of Political Science 54 (1):209-28. 
Rheault, Ludovic, and Christopher Cochrane. 2020. Word Embeddings for the Analysis of Ideological Placement in Parliamentary Corpora. Political Analysis 28 (1):112-33.

Round, Jeffery I., and Matthew Odedokun. 2004. Aid Effort and its Determinants. International Review of Economics \& Finance 13 (3):293-309.

Slapin, Jonathan B., and Sven-Oliver Proksch. 2008. A Scaling Model for Estimating Time-series Party Positions from Texts. American Journal of Political Science 52 (3):705-22.

Smith, Brian H. 2014. More Than Altruism: The Politics of Private Foreign Aid. Princeton University Press.

Stokke, Olav. 1996. Foreign aid towards the year 2000: experiences and challenges. Frank Cass and Co. Ltd.

Thérien, Jean-Philippe. 2002. Debating Foreign Aid: Right versus Left. Third World Quarterly 23 (3): $449-466$.

Thérien, Jean-Philippe, and Alain Noel. 2000. Political Parties and Foreign Aid. American Political Science Review 94 (1):151-62.

Warntjen, Andreas. 2012. Measuring Salience in EU Legislative Politics. European Union Politics 13 (1):168-82. 


\section{Online Appendices}

Appendix 1: Coding Scheme for Categorization of Domestic Aid Constituency

Appendix 2: Aid Testimonies at the US Congressional Hearings, 1980-2013, Codebook

Appendix 3: Full Results and Robustness Checks in Respect to the Number of Topics

Appendix 4: The Interaction of Domestic-International Aid Discourses 


\section{Appendix A: Coding Scheme for Categorization of Domestic Aid Constituency}

In my corpus, non-departmental witnesses who testified in the U.S. Congressional hearings are categorized into either development NGOs or private enterprises, based on the characteristics of the groups they represent in their testimonies. The list of domestic constituencies only includes the U.S.-based interest groups, and therefore, e.g., the UN officials were excluded in the sample.

Primarily, the aid constituency category that distinguishes between development NGOs and private enterprises depends on whether an organization is a non-profit or profit organization. For example, the NGO constituency in my corpus is mostly composed of the Private Voluntary Organizations (PVOs). Likewise, many groups classified to the firm constituency apparently reveal their identity of for-profit organizations with their company names: e.g., Inc., Co., Corp., or Ltd.

However, one important thing to note is that, as stated in the main text, both the NGO and firm constituent groups organize network associations and send them as witnesses to foreign aid hearings in an attempt to collectively represent their common interests. Such network bodies are basically non-profit organizations, but private enterprises also create umbrella organizations as a channel for pursuing their commercial interests. Therefore, in the case of network associations, I classified the organizations according to the characteristics of their member organizations. Examples of network bodies for NGOs and firms in the U.S. are [NGOs]: Interaction, Interreligious Task Force on U.S. Food Policy and [Firms]: Coalition for Employment through Exports, American Wind Energy Association, The Micro-Enterprise Coalition.

Some of the organizations in the respective category of NGO and firm constituencies:

1. The NGO Constituency

- Private Voluntary Organizations (PVOs)

- U.S. branches of global federations (INGOs): Cooperative For American Relief Everywhere (CARE International); Oxfam America; World Vision; Save the Children

- Religious Charities: Bread for the World; Catholic Relief Services; Holt International

- Grassroots organizations: The Sierra Club

- Watchdogs / Policy Advocacy: Human Rights Watch; Environmental Defense Fund

- Service Provisions: Helen Keller International

- Non-profit think-tanks: Center for Global Development; Brookings Institution

- Research Centers and Institutes (Universities): Georgetown University Center for Intercultural Education and Development; Environmental Policy Institute

2. The Firm Constituency

- U.S. branches of multinational corporations (MNCs): General Electric; Combustion Engineering; Motorola Inc.; M.W. Kellogg Ltd.; Coca-Cola Co. 
- Individual companies: Spire Corp.; Bergey Windpower Co.; Enron Development Corporation

- Private financial institutions: Tig Insurance Company; Bank of America

- Trade unions: Credit Union National Association, National Foreign Trade Council

- Agricultural producers: Eastern U.S. Agricultural And Food Export Council

- Consulting firms: World Perspectives Inc.; Baker Botts

- Advisory firms: The Scowcroft Group

- Lobbying firms: Solar Unity Network

- Co-op (Cooperatives): Land O'Lakes Inc.

- Business policy think-tanks: Kenan Institute of Private Enterprise

Below, Figure A7 reports the numbers of individual groups and network associations that testified in aid hearings every year representing the NGO and firm constituents, respectively. One thing worth noting is that in the case of firm constituents, more groups testified through network associations in the earlier period than individually testifying (purple space), whereas individual firms actively engaged with the hearings after mid 1990s (blue space). By contrast, in general, more NGOs individually testified than did they so through network bodies. However, such gap had narrower after mid 1990s (blue space).
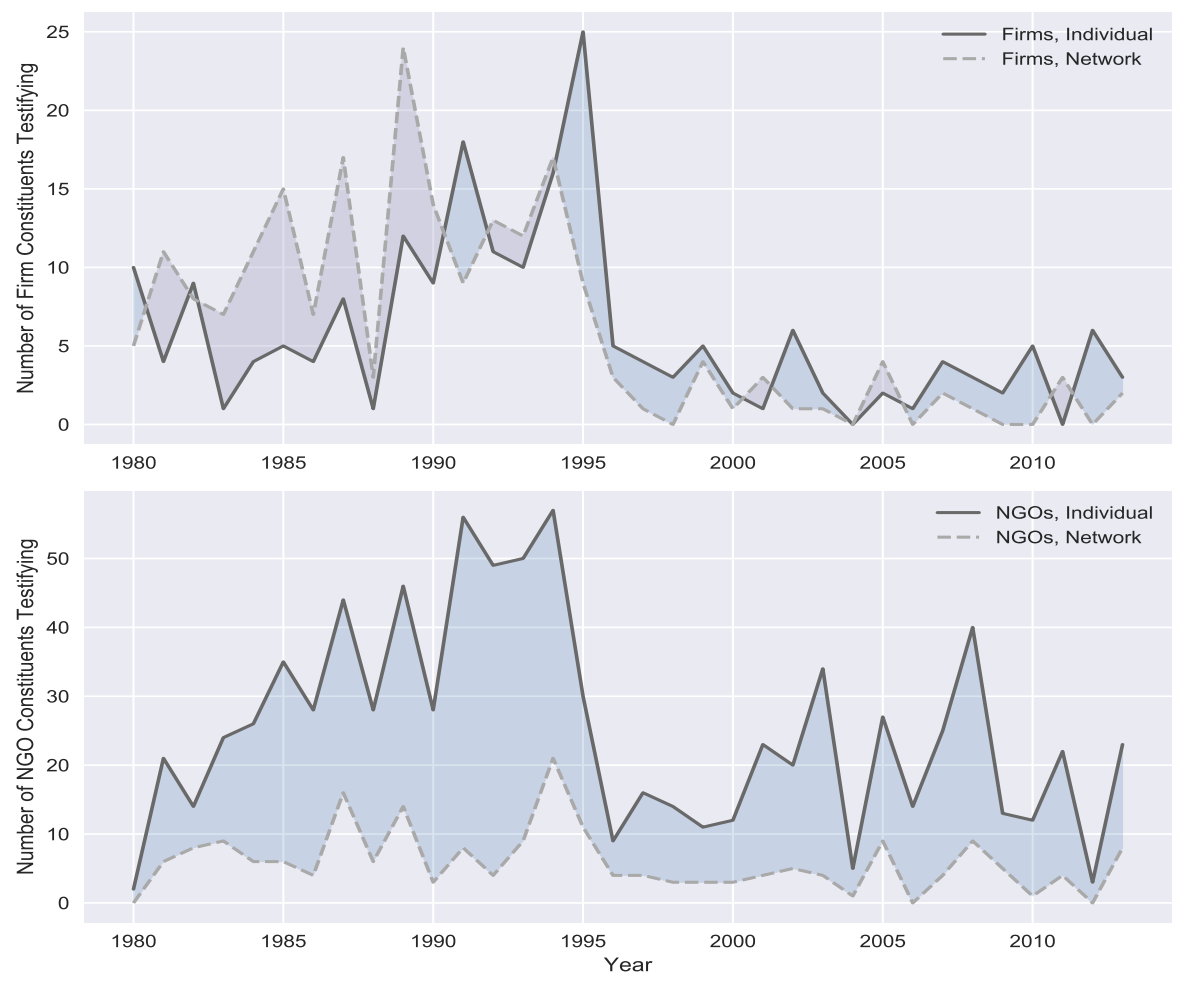

Figure A7: The Number of NGO and Firm Constituents by Organization Type in the Sample, 1980-2013. 


\section{Appendix 2: Aid Testimonies Given by Domestic Constituencies in the US Congressional Hearings, 1980-2013 Codebook}

Goal: I seek to generate text data on domestic constituent group's issue emphasis on foreign aid as provided by their testimonies. Beyond the traditional measures such as which groups and how many times the groups have participated in hearings, this study focuses on the contents of testimonial statements as an important source of data as an endeavor to transforming these political texts to meaningful numbers. The testimonies made by non-departmental witnesses will reveal the procedure of reflecting competing domestic claims relating to foreign aid.

Source: Proquest Congressional

Date: $01 / 01 / 1980$ - 12/31/2013

Raw data format: PDF-format

The unit of observation is an individual witness (more specifically, witness-constituent-year) whose testimonial statements are recorded where he or she represents the interests of the constituent group. The dataset consists of the following variables:

- CITATION: Citation number of hearing case.

- WITNESS_NAME: name of the witness who made testimonial statements in a given hearing.

- WITNESS_GROUP: name of the group and status of the witness in the group.

- TITLE: Title of the hearing case.

- STARTDATE: Start date of the hearing case. (mm-dd-yyyy)

- COMMITTEE: Committee name in which the hearing case was held.

- CONGRESS: A categorical variable of House / Senate / Joint.

- TEXT: A testimonial statement that the witness made in a given hearing.

- CONSTITUENTS: Name of the constituent group that a witness represents. If a witness is from an individual group but represents an umbrella organization in his or her testimony, the name of the latter, the umbrella association, is recorded. The name of individual group can be found in WITNESS_GROUP.

- CONSTITUENTS_TYPE: Type of the constituent group (A dummy variable of NGO / Firm)

- CONSTITUENTS_ORG: A categorical variable of Individual / Network / Both. Both indicates a case where a witness identifies the name of an individual group that he or she belongs to but testifies as a representative of a network association. 
- TEXT_TOKENS: TEXT variable, tokenized, not pre-processed (with procedural and stop words).

- TEXT_TOKENS_LEM: TEXT_TOKENS variable, pre-processed.

- TOKEN_COUNT: The total number of tokens (words) used in the given statement.

Scope of the Corpus:

- The total number of hearings published in Proquest Congressional with a search term "foreign aid" is 1,472 . Out of 1,472 returns, I only counted hearing cases and testimonial statements under the following categories:

- Hearings where domestic interest groups (i.e., non-departmental) testified as witnesses. That said, hearings only composed of legislative and/or executive bodies were excluded. $\mathrm{UN}$ officials cases are also excluded in the sample.

- The overall statements of a witness' testimony in a given hearing should be directly related to foreign aid. As a bare minimum method to verify this, I only counted testimonies where a witness mentions either "aid" or "assistance" at least once in her testimony. I also, as a human coder, read all the statements to decide whether the given statement is relevant or not.

- If a hearing title encompasses broader issues than foreign aid (e.g., US-Pakistan Relations, Foreign Economic Relations with Latin America), I only took the panel(s) and witness(es) whose testimony topics mainly address foreign aid.

- Witnesses and their testimonies must represent an organization that they belong to and the organization's interests. That said, witnesses who participate individually or who are from an organization and yet, appearing in their own individual capacity and explicitly mentioning in their speech that their opinions do not represent the organizations were excluded.

- In a given statement, I removed some phrases of opening and closing speeches where individual witnesses expressed their gratitude to the Chairman and the Committee members and/or introduced what their organizations do that they represent.

Preprocessing:

- PDF-TXT conversion: I converted testimonies in a PDF format to TXT-files. To make sure that key words in a given testimony are not misspelled due to the errors often occurring in the conversion procedure, I used a spelling checker and compared the converted text data with the original PDF-file. More specifically, I copied and pasted each statement converted in TXT format from Python to Microsoft Word and corrected the misspelled words. I, as a human coder, read through all the preprocessed texts one by one to check whether all words were correctly converted.

- I removed stop words, organization names, and non-alpha characters (digits and characters).

- I removed overly used procedural words such as 'speaker', 'chairman/chairwoman', 'Senate', 'House', 'testimony', 'thank', 'committee' with the individual names attached afterwards: e.g., Chairman Dorgan. 
Table A5. The List of Committees Related to Foreign Aid in the Corpus, 1980-2013.

\begin{tabular}{llll}
\hline \hline & Congress & & \multicolumn{1}{c}{ Committee } \\
\hline 1 & House & Committee on Appropriations & 483 \\
2 & & Committee on Foreign Affairs & 231 \\
3 & & Committee on International Relations & 91 \\
4 & & Committee on Agriculture & 89 \\
5 & & Committee on Hunger. Select. & 61 \\
6 & & Committee on Banking, Finance, and Urban Affairs & 24 \\
7 & & Committee on Financial Services & 21 \\
8 & Committee on Oversight and Government Reform & 13 \\
9 & Committee on Energy and Commerce & 11 \\
10 & & Committee on Banking, Housing, and Urban Affairs & 9 \\
11 & & Tom Lantos Human Rights Commission & 8 \\
12 & Committee on Banking and Financial Services & 5 \\
13 & Committee on Armed Services & 3 \\
14 & Committee on Merchant Marine and Fisheries & 3 \\
15 & Committee on Ways and Means & 3 \\
16 & Committee on the Budget & 3 \\
17 & Committee on Government Reform & 2 \\
\hline 1 & Joint & Economic Committee. Joint. & 9 \\
\hline 1 & Senate & Committee on Appropriations & 173 \\
2 & & Committee on Foreign Relations & 146 \\
3 & Committee on Agriculture, Nutrition, and Forestry & 35 \\
4 & Committee on Banking, Housing, and Urban Affairs & 14 \\
5 & Committee on Homeland Security and Governmental Affairs & 8 \\
6 & Committee on Banking, Finance, and Urban Affairs & 6 \\
7 & Committee on Finance & 6 \\
8 & Committee on Indian Affairs. Select. & 4 \\
9 & Committee on Energy and Natural Resources & 3 \\
10 & Committee on Small Business & 3 \\
11 & Committee on the Judiciary & 3 \\
12 & Committee on Governmental Affairs & 2 \\
\hline & &
\end{tabular}




\section{Appendix 3: Robustness Checks in Respect to the Number of Topics}

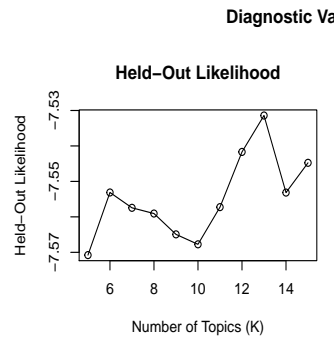

Semantic Coherence

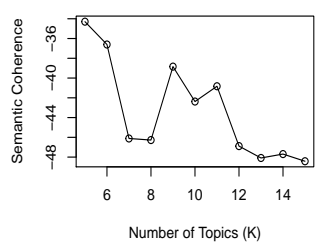

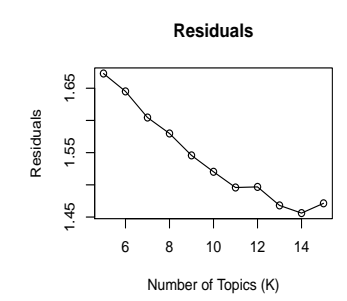

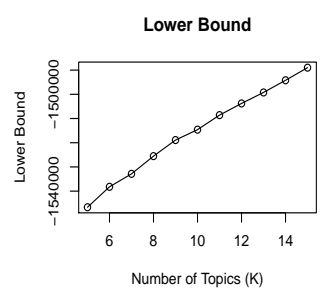

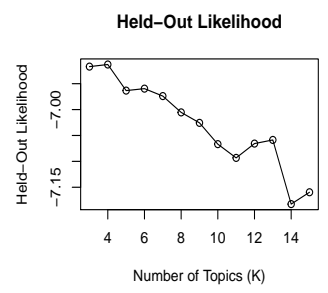

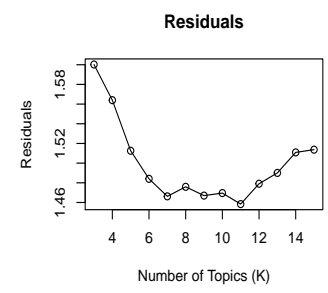

Semantic Coherence
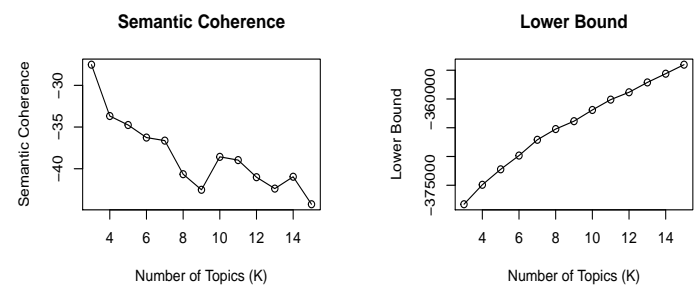

(a) NGOs’ Testimonies

(b) Firms' Testimonies
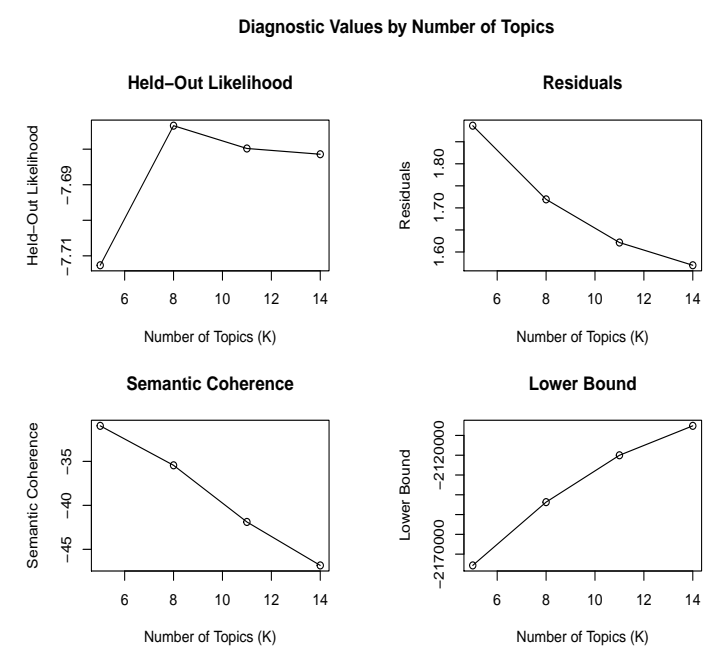

(c) The Entire Testimonies

Figure A8: Semantic Coherence and Exclusivity According to the Number of Topics. Models (a)\&(b) were estimated against different topic numbers, $K$ for NGOs and $N$ for firms, through the iteration ranging from 3 to 15 . In the models with $\mathrm{K}<6, \mathrm{~N}<5$, many issues overlapped and, therefore, were not distinct from each other, whereas in the models with $\mathrm{K}>6, \mathrm{~N}>5$ semantic validity was not maintained as each topic identified was not comprehensive enough to incorporate its elements (words) and, therefore, did not fully represent each cluster in a meaningful way. The final Model (c) fits 8 topics with the CONSTITUENT TYPE variable as a covariate. While the 8 topic model categories are best tuned to incorporate the common issues that both the NGOs and firms emphasized in their testimonies, as my theory expects, both groups of constituencies have different sectoral interests and, therefore, both groups do not fully converge on some topic dimensions. Further details can be found in Table A6. 


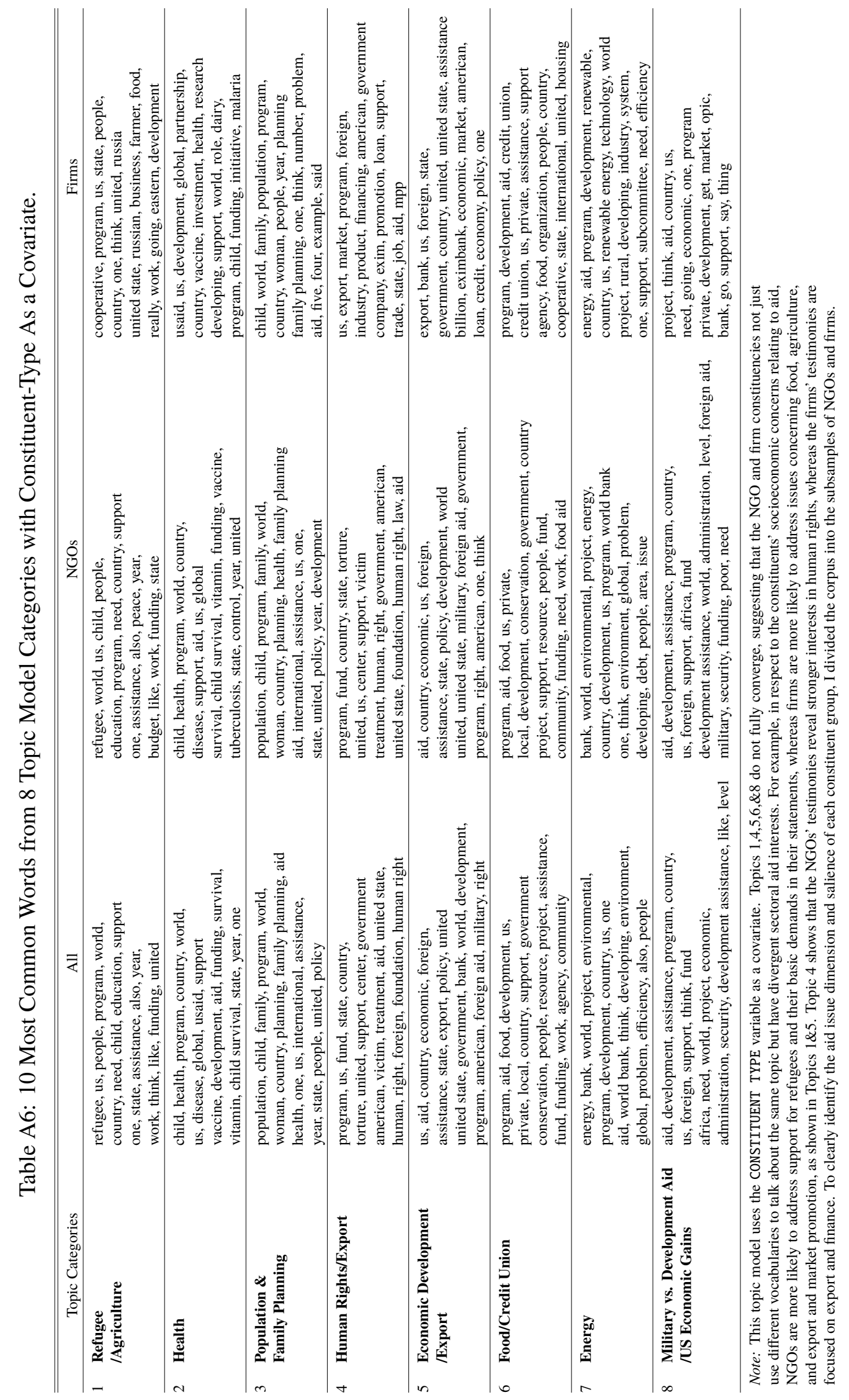




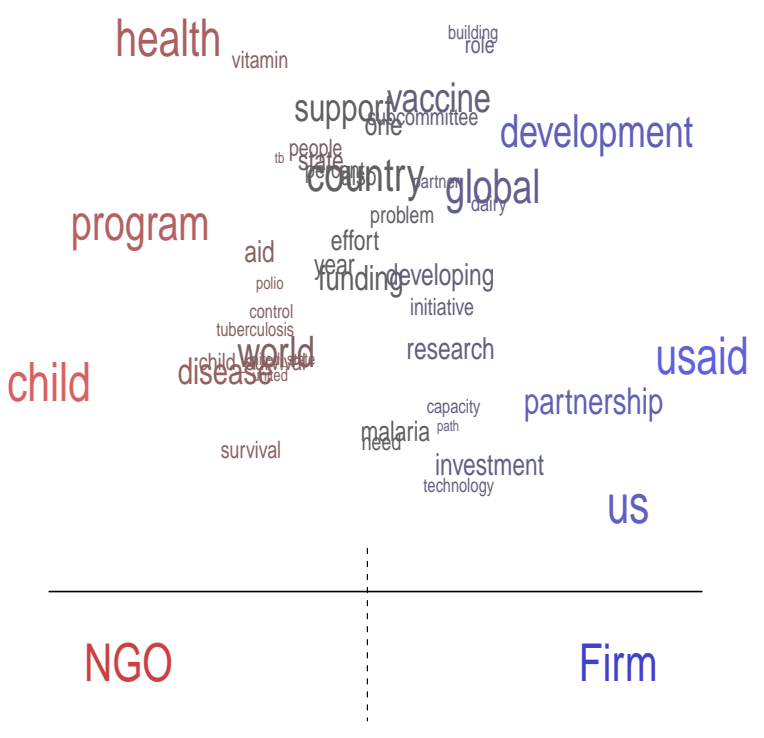

(a) Health

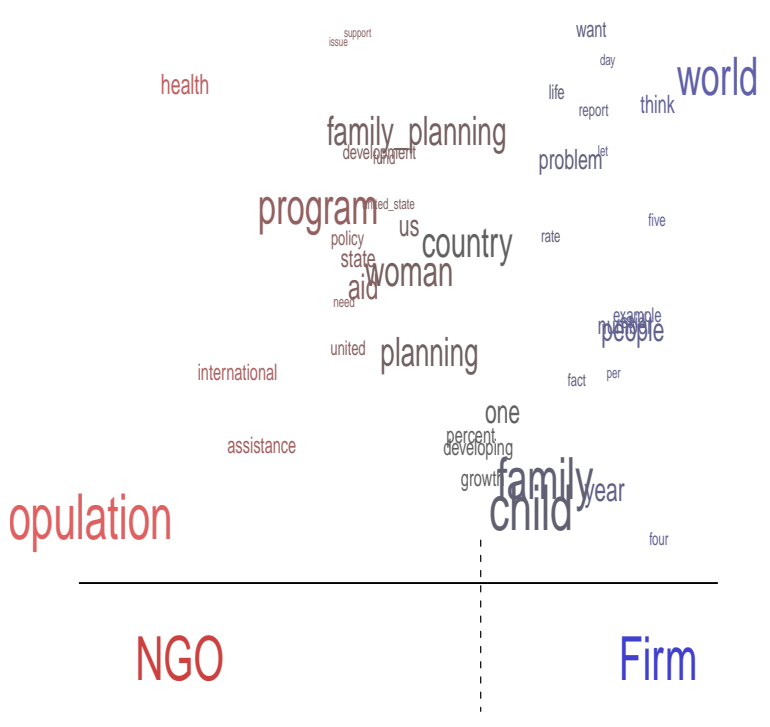

(b) Population and Family-Planning

\section{Figure A9: Word Clouds for the NGOs and Firms on Health and Family-Planning Topic}

Dimensions. Both the NGOs and firms tend to display similar concerns in their testimonies in the health and population topic categories as opposed to the energy aid topic. For example, in respect to health issues relating to aid, the firms emphasize vaccine development investment in terms of research and technology in partnership with the USAID. The NGOs emphasize their interest in aid funding for health and nutrition programs focusing on child survival. For population issues, both the firms and NGOs focus on the US assistance for family planning and reproductive health programs overseas. 


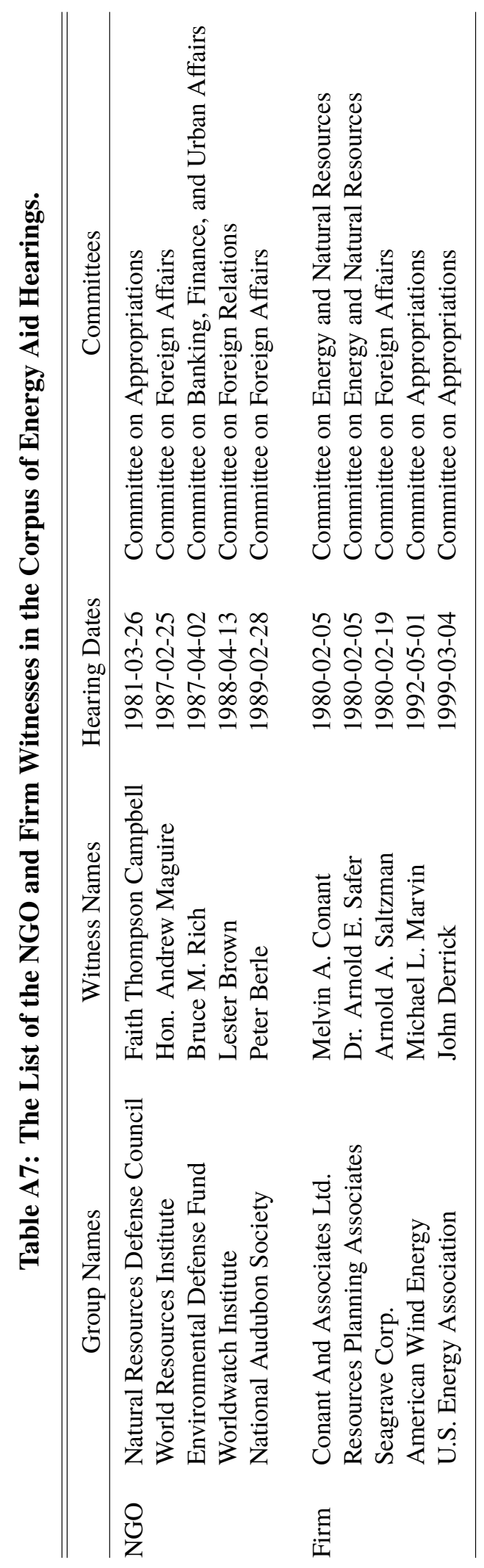


Appendix 4: The Linkage in the Domestic-International Aid Discourses
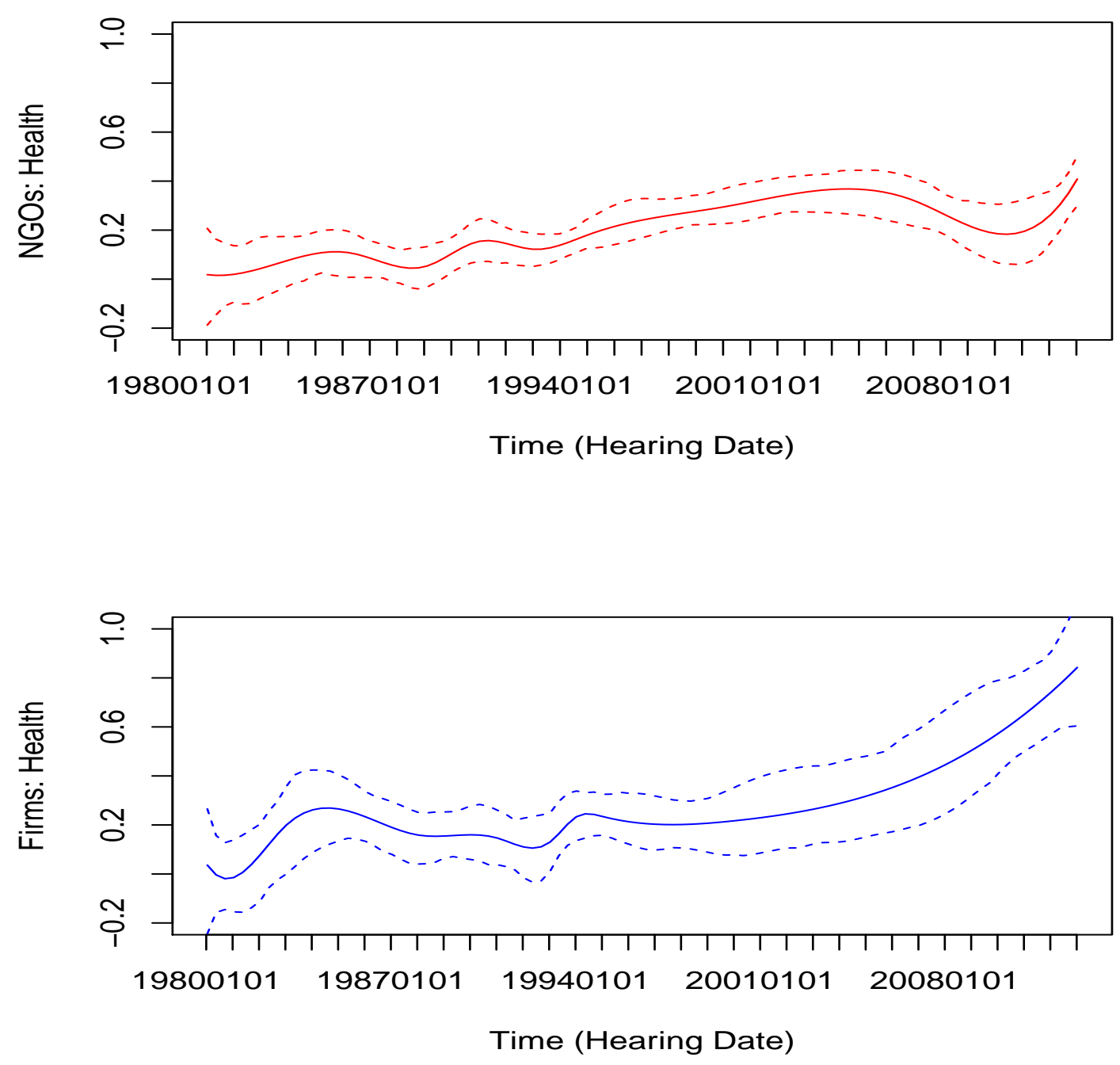

Figure A10: The Expected Topic Proportions for Health in NGOs' and Firms' Testimonies, 1980-2013. The prediction lines show that the prevalence of health aid topics that both the NGOs and firms advocate for in their testimonies increased over time, especially the firms in the post-Millennium Development Goals era (after 2000). 